Review

\title{
Functionalisation of Colloidal Transition Metal Sulphides Nanocrystals: A Fascinating and Challenging Playground for the Chemist
}

\author{
Silvia Gross ${ }^{1,2, *}$, Andrea Vittadini ${ }^{1,2}$ and Nicola Dengo ${ }^{1,2}$ \\ 1 Istituto di Chimica della Materia Condensata e di Tecnologie per 1'Energia, ICMATE-CNR, via Marzolo 1, \\ I-35131 Padova, Italy; andrea.vittadini@unipd.it (A.V.); nicola.dengo@phd.unipd.it (N.D.) \\ 2 Dipartimento di Scienze Chimiche, Università degli Studi di Padova and INSTM, UdR Padova, \\ via Marzolo 1, I-35131 Padova, Italy \\ * Correspondence: silvia.gross@unipd.it; Tel.: +39-049-827-5736
}

Academic Editor: Roberto Comparelli

Received: 27 December 2016; Accepted: 24 March 2017; Published: 14 April 2017

\begin{abstract}
Metal sulphides, and in particular transition metal sulphide colloids, are a broad, versatile and exciting class of inorganic compounds which deserve growing interest and attention ascribable to the functional properties that many of them display. With respect to their oxide homologues, however, they are characterised by noticeably different chemical, structural and hence functional features. Their potential applications span several fields, and in many of the foreseen applications (e.g., in bioimaging and related fields), the achievement of stable colloidal suspensions of metal sulphides is highly desirable or either an unavoidable requirement to be met. To this aim, robust functionalisation strategies should be devised, which however are, with respect to metal or metal oxides colloids, much more challenging. This has to be ascribed, inter alia, also to the still limited knowledge of the sulphides surface chemistry, particularly when comparing it to the better established, though multifaceted, oxide surface chemistry. A ground-breaking endeavour in this field is hence the detailed understanding of the nature of the complex surface chemistry of transition metal sulphides, which ideally requires an integrated experimental and modelling approach. In this review, an overview of the state-of-the-art on the existing examples of functionalisation of transition metal sulphides is provided, also by focusing on selected case studies, exemplifying the manifold nature of this class of binary inorganic compounds.
\end{abstract}

Keywords: metal sulfides; transition metal sulfides; colloids; nanocrystals; functionalization; surface chemistry; bioimaging; derivatization; modelling; zinc sulfides; molybdenum sulfides

\section{Introduction}

The present review aims at providing a broad, though not comprehensive, overview of the functionalisation of metal (and in particular transition metal) sulphides, focusing on colloidal sulphide nanocrystals (NC). This wide and diversified class of inorganic materials has been the topic of several contributions, addressing their synthesis and characterisation [1-36], functionalisation [37-40], surface chemistry and eventually applications $[1,6-11,15,27,30,33,35,41-49]$.

Nanocrystals present features which are different from those of bulk materials, particularly at the surface. With respect to bulk surfaces, nanocrystals present different and/or additional properties as a results of reduced size. In fact, a bulk solid contains only a small percentage of surface atoms; as a result, broken chemical bonds on the outer part contribute only minimally to material properties [50]. The surface-to-volume ratio increases inversely with shrinking size, and consequently the surface contribution increases in relevance, eventually becoming dominant. At the nanoscale, reduced size 
can significantly alter some properties (for example optical properties) and generate completely new effects (such as surface plasmon resonance or size-dependent catalytic activity [51-56].

The review will therefore provide an overview on metal sulphide NCs surface chemistry and on the functionalisation of these surfaces, with particular emphasis on functionalisation strategies for biomedical applications, though other application fields will be also mentioned. Ligands exchange strategies will also be shortly surveyed, though this is not the main focus of the contribution.

Using the above reported state of the art as a starting point, the present work will aim not only at covering and updating the information addressed by the above quoted references, but also at complementing the topics addressed by these reviews from three points of view. In particular, compared to the aforementioned extended reviews, this work will focus on aspects such as:

1. efforts toward the unambiguous characterisation and assessment of metal sulphides surfaces, which is still an open issue, and a lively debate on it is present in the literature.

2. the development of effective functionalisation strategies for metal sulphides surfaces which requires a careful consideration of the former point;

3. survey the combination of experimental and computational tools to unravel the exact nature of functional groups and moieties present on the sulphide surface.

Accordingly, due to the vastness of the topic and to space constraints, in this Review, which has not the goal to provide a thorough and comprehensive coverage of this huge and widespread field, only a selection of case studies will be addressed. The whole corpus of works on the topic will be not considered, as it is extensively reviewed in the aforementioned given references, to which interested readers are referred.

Nevertheless, a few significant examples of convincingly performed functionalisations will be reviewed and discussed. The selection has been performed on two levels:

- $\quad$ selected different substrates (i.e., molybdenum, iron, copper and zinc sulphide) were chosen as examples of functionalised metal sulphides;

- $\quad$ selected functionalisation routes and moieties.

The structure of the Review entails a general introduction on metal sulphides and in particular on transition metal sulphides, as well as a discussion on the most relevant analogies and differences with respect to the homologues oxides. This latter part is relevant and functional also to the following discussion on the comparison of the functionalisation strategies for these two classes of inorganic colloids, being those for the latter ones (i.e., oxides) well established and thoroughly reported in the literature. The state-of-the-art in the corresponding field for the sulphides is instead not homogeneous, incomplete and in many cases contradictory, as explained in Sections 2.2 and 2.4 of this review. A section dealing with functionalisation of these compounds is then presented. The Section 2.3 deals with nanocrystals-ligands interactions.

The penultimate (Section 3) is devoted to an overview on selected case studies chosen to demonstrate the various solutions developed to stabilise transition metal sulphides colloids.

For each analysed substrate (i.e., metal sulphide), a brief description of the most relevant properties and applications (mainly in the field of bio-related applications such as bioimaging, in the field of inks and thin films, and in the field of electronics and opto-electronics) of the considered chalcogenide is provided, followed by relevant state-of-the-art examples. These are indeed selected to present in the most comprehensive fashion the manifold variability in terms of chemical nature of the surface and of the moieties used to strongly interact with it. Finally, the last part of the review is devoted to draw some conclusions, but chiefly to outline possible developments and perspectives in this highly fascinating field of research. 


\section{Transition Metal Sulphides: General Features and Surface Chemistry}

In this section, we address firstly (Section 2.1) the main chemical and structural features of metal sulphides, by outlining the differences and analogies with respect to the homologues with oxygen, i.e., metal oxides. In the following (Section 2.2), the features of surface of transition metal sulphides, both as bulk materials as well as nanocrystals are surveyed, by discussing main model systems. A third sub-chapter, Section 2.3, is devoted to the description of some relevant example and on the main findings concerning the complex nature of interactions between ligands and nanocrystals surface. This is a more general part, mostly dealing with oxide NCs, though many considerations and methodological approaches can be extended to sulphides. In the last Section 2.4, applications of transition metal sulphides and the main functionalisation approaches to pursue these applications are reviewed.

\subsection{Transition Metal Sulphides: Analogies and Differences with Respect to Transition Metal Oxides}

Metal sulphides are a very broad and variable class of binary materials, having the general formula $\mathrm{M}_{\mathrm{x}} \mathrm{S}_{\mathrm{y}}$ [57-61].

The structures and properties of most metal sulphides are remarkably different from those of the parent metal oxides. This has partially to be ascribed to the stronger covalence of the metal-sulphur bond, as extensively described in the following (vide infra), which reflects in a broader variety of accessible structures. For instance, contrary to the oxides homologues, sulphides present also stable structures characterised by the metal in trigonal-prismatic coordination and by the formation of S-S bonds, which are instead not observed in the metal oxides [57]. As thoroughly discussed in the following, the higher polarisability of the sulphide anion with respect to the harder (in Pearson's terms, [62]) oxide counterparts enables also the formation of layered structures, such as $\mathrm{MoS}_{2}$ or $\mathrm{WS}_{2}$, based on van der Waals interactions among the layers.

The main differences in terms of chemical reactivity and properties between metal oxides [63] and metal sulphides may be rationalised by referring to the different atomic numbers and sizes of oxygen and sulphur atoms and of the corresponding negative divalent anions (the ionic radius of the oxide ion ranges between 1.35 and $1.42 \AA$ [64], while the $\mathrm{S}^{2-}$ ionic radius amounts to $1.84 \AA$ [64,65]. As a consequence of the larger size of the atoms, sulphur is also characterised by a much higher average polarisability $\left(\alpha_{S}=2.90\right.$ in units of $\left.10^{-24} \mathrm{~cm}^{3}\right)$ with respect to oxygen $\left(\alpha_{O}=0.802\right.$ in units of $10^{-24} \mathrm{~cm}^{3}$ ) [66], which allows to classify $S$ and $O$ donor atoms as soft and hard, respectively [62]. In this regard, it can be also useful to remind that the Pauling sulphur electronegativity (2.5) is significantly lower that the $\mathrm{O}$ one (3.5) [67] thus indicating a M-S bond much more covalent than the $\mathrm{M}-\mathrm{O}$ one. A further important consequence of the lower electronegativity of sulphur is its lower tendency to form hydrogen bonds. The higher covalent character of the $\mathrm{M}-\mathrm{S}$ interaction in $\mathrm{M}_{\mathrm{x}} \mathrm{S}_{\mathrm{y}}$ binary compounds has important consequences on the structures and chemical properties of $\mathrm{M}$ sulphides. A thorough discussion of the structural chemistry in metal and transition metal sulphides is reported in general inorganic textbooks [57-61].

In some cases, the $\mathrm{M}_{\mathrm{x}} \mathrm{S}_{\mathrm{y}}$ structures are quite similar to those of the corresponding oxides (for instance, the cubic $\mathrm{MnO}$ and the most stable polymorph of MnS have the same structure (rock salt), but quite different chemical and functional features). On the other side, there are several further oxides and sulphides which, even though characterised by the same stoichiometry, show striking structural differences. For instance, in the case of $\mathrm{Cu}(\mathrm{II})$, the oxide tenorite and the corresponding sulphide covellite (i.e., $\mathrm{CuO}$ vs. $\mathrm{CuS}$ ) [57,59], though characterized by the same formal 1:1 stoichiometry, feature very different structural arrangements, the latter compound presenting also S-S disulphide bonds [68].

Transition metal (TM) sulphides are particularly fascinating because of the structural variability and highly interesting functional properties [57-59,61], deriving not only by the nature of the involved transition metal, but also from variability in structure and stoichiometry. In fact, some of them present very complex structures not displaying a unique stoichiometry, for instance determined by other factors, such as atomic sizes and the possibility to form S-S bridges. The broad class of sulfur-rich 
metal sulphides is characterised by the presence of $S_{n}{ }^{2-}$ polysulphide anions. Besides well know polysulphides of alkaline and earth alkaline metals, having a $\mathrm{M}_{2} \mathrm{~S}_{n}$ stoichiometry $(n=2$ for $\mathrm{Na}, n=2-6$ for $\mathrm{K}, n=6$ for Cs) or $\mathrm{BaS}_{\mathrm{n}}(n=2,3,4)$, there are also TM polysulphides, such as $\mathrm{VS}_{4}, \mathrm{Re}_{2} \mathrm{~S}_{7}$ and the trisulfide $\mathrm{TiS}_{3}, \mathrm{ZrS}_{3}, \mathrm{HfS}_{3}$, formally written as $\mathrm{M}^{4+} \mathrm{S}^{2-}\left(\mathrm{S}_{2}\right)^{2-}$ and based on both sulphide and disulphide ions and displaying unusual structures [57,59].

Metal disulphides, having the formal stoichiometry $\mathrm{MS}_{2}$, are a relevant class of TM sulphides, also from the technological point of view. They crystallise in three different structures $\left(\mathrm{CdI}_{2}\right.$-type, $\mathrm{MoS}_{2}$-type, pyrite-type, e.g., $\mathrm{Fe}_{2} \mathrm{~S}$ ) [57]. Metal disulphides of the groups 4, 5, 6 form layered structures in which the metal atoms occupy trigonal anti-prismatic or trigonal-prismatic voids. The structures are built up of different layers characterised by S-M-S bonds. [35,48]. Chalcogenide atoms in two hexagonal planes are separated by a plane of metal atoms, and the formal valence states of metal (M) and chalcogen $(X)$ atoms are +4 and -2 , respectively.

As a further function-relevant feature, some transition metal chalcogenides systems are characterised by either small (such as in the case of ZnS) or large deviation from the formal stoichiometry [69]. In the former case, the deviations from 1:1 stoichiometry result from lattice disorder arising from the presence, in small concentrations, of vacancies or interstitials. The latter case is instead much more represented among transition metal sulphides, which can exist as homogeneous phases over rather large composition ranges. This range usually, but not always, encompasses some simple stoichiometric composition. This stoichiometry variability is made possible by the presence of native structural defects built into the crystalline lattice.

In this regard, the structures of different iron and copper sulphides characterized by different S:M stoichiometry are depicted in Figure 1.
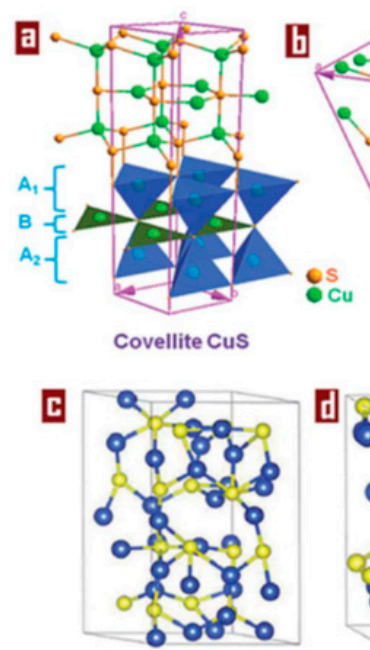

High-Chalcocite $\mathrm{Cu}_{2} \mathrm{~S}$

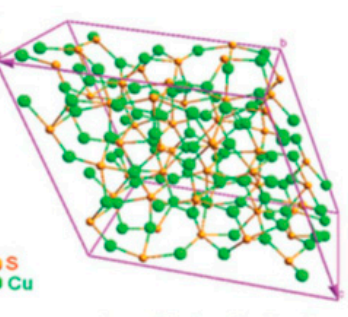

Low-Chalcocite $\mathrm{Cu}_{2} \mathrm{~S}$

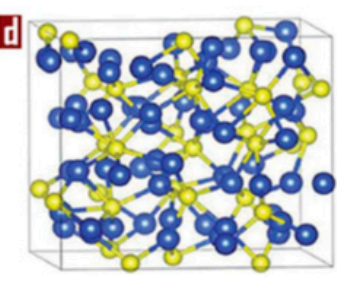

Cubic-Chalcocite $\mathrm{Cu}_{2} \mathrm{~S}$

A

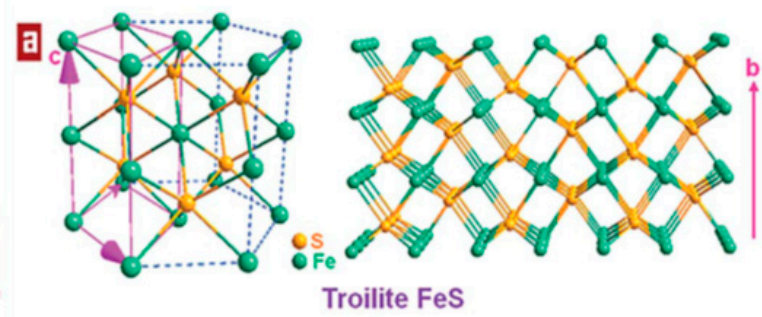

田

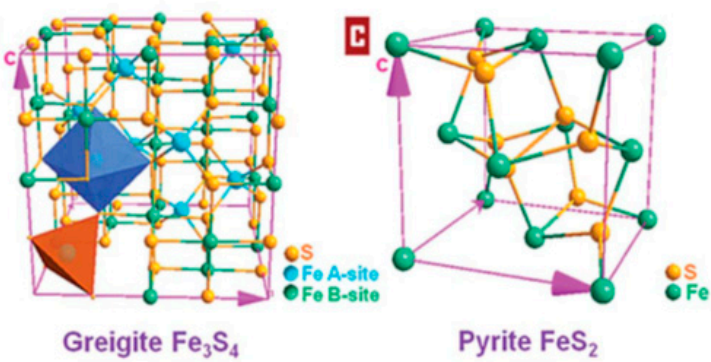

B

Figure 1. (A) Crystal structures of (a) covellite CuS consisting of layers triangular $\mathrm{CuS}_{3}$ units (layer B) surrounded by $\mathrm{CuS}_{4}$ tetrahedra (layers A1 and A2), (b) low-chalcocite (monoclinic), (c) high-chalcocite (hexagonal) and (d) cubic-chalcocite (cubic) $\mathrm{Cu}_{2} \mathrm{~S}$. (B) Crystalline structures of stoichiometric (a) troilite $\mathrm{FeS}$ along different directions, (b) greigite $\mathrm{Fe}_{3} \mathrm{~S}_{4}$, and (c) pyrite $\mathrm{FeS}_{2}$. Taken from Ref. [27]. Reproduced with permission of Royal Society of Chemistry.

For a thorough and comprehensive description of the rich chemistry of metal sulphides, the interested reader is referred to inorganic chemistry textbooks [57-61] and to the cited dedicated reviews.

Synthetic routes for the reproducible and phase-controlled preparation of metal sulphide colloids are of fundamental interest for the study of the mentioned properties at the nanoscale level. Limiting the attention to wet chemistry approaches, a wide plethora of synthetic routes has 
been proposed in the literature to prepare metal sulphide colloids ranging from non-aqueous sol-gel routes [70-73], hydro/solvothermal [24,74-86], to sono- [19,87-110] and radiochemistry [111-117], laser ablation [118,119], micro- [120-130] and miniemulsion synthesis [131-138], seeded-growth [139] and nucleation/growth and general colloidal and precipitation/co-precipitation approaches [13,82,140-153]. Recently, microbial, biomimetic and biogenic environmentally friendly synthesis of metal sulphide nanoparticles by using microbacteria, fungi, yeast has been also explored and thoroughly reviewed $[5,9,15,154-159]$.

A comprehensive collection of wet-chemistry routes to metal sulphides is reported in the cited review papers $[6,15,47,123,160-162]$ and in the above given specific references. In reference [161], a comprehensive table is reported, collecting many of the wet chemistry routes used to produce, inter alia, different sulphides and other chalcogenides. Transition metal sulphides such as $\mathrm{Ag}_{2} \mathrm{~S}, \mathrm{CuS}$, $\mathrm{CdS}$, and $\mathrm{ZnS}, \mathrm{FeS}_{2}$, which can be formed either directly from their precursors ions or indirectly by sulphide ion-assisted conversion of the corresponding metal oxide, typically under anaerobic conditions, have been the focus of recently appeared review [163].

Metal sulphides NCs can be also produced in a controlled fashion by reaction of metal salts with tailor-made sulphide precursors, such as bis-(trimethylsilyl) sulfide [(TMS) $\left.{ }_{2} \mathrm{~S}\right]$, phosphines sulphides $\left(\mathrm{R}_{3} \mathrm{P}=\mathrm{S}\right.$, where $\mathrm{R}$ indicates an alkyl or aryl group), and hydrogen sulfide produced by heating elemental sulfur in alkane or amine solvents. By following this precursor-based approach, the synthesis of size-controlled sulphide NCs (lead sulfide, cadmium sulfide, zinc sulfide, and copper sulfide) has been recently afforded by Owen and co-workers [13] by using a library of tri-substituted thioureas. The conversion reactivity to the targeted sulphide was determined by the substitution degree and in particular by the electronic and steric features of the substituents in the thiourea. By controlling the monomer supply kinetics, the extent of nucleation in syntheses of the NCs and the size distribution could be controlled.

\subsection{The Surface of Transition Metal Sulphides: Bulk and Nanocrystals}

Surface chemistry of metal sulphide, as already outlined above, is not so widely explored and studied as the one of the oxides homologues. As Balantseva et al. [164] pointed out, whereas literature concerning in situ infrared studies of surface of oxide materials is very abundant [165-167], the one on sulphides is instead quite limited. Some works were reported about the surface properties of unsupported or supported $\mathrm{MoS}_{2}$, an increasingly studied catalyst for hydrodesulphurisation [168].

Progress in the knowledge of metal sulphides surface chemistry has been spurred by the need of improved mineral processing technologies. In this regard, it suffices to cite the separation of sphalerite $\mathrm{ZnS}$ from less valuable mineral by froth flotation, which is hampered by the presence of undesirable components such as pyrite. Further interest on the surface reactivity of metal sulphides has been recently driven by concerns on the impact of the products of mining operations, by catalysis (most notably desulphurization), and by the self-assembly and functionalization of organic molecules [45].

As outlined in previous reports on the topic [164], one of the reasons for this lack or scarcity of information on the surface chemistry of metal sulphides could be ascribed to the intrinsic difficulties in handling this class of materials. Whereas in the case of oxides, in situ surface studies are usually carried out on clean surfaces, obtained by removing species adsorbed from the atmosphere or residual synthetic reactants by calcination/oxidation treatments in flow or static conditions, the same cannot be stated for sulphides. A very general tendency of most metal sulphide, making the study of their surface chemistry even more challenging, is the possibility to get easily oxidised to oxides or sulphates $[45,61,169,170]$, as extensively reported in the given references. It is for instance well-known that calcination at temperatures as high as $773 \mathrm{~K}$ promotes the transition from $\mathrm{ZnS}$ to $\mathrm{ZnO}$. Even if oxidation is carried out in controlled conditions, by avoiding the complete $\mathrm{ZnS} / \mathrm{ZnO}$ phase transition, treatment with oxygen or water vapour was shown to cause the formation of surface sulfate $\left(\mathrm{SO}_{4}{ }^{2-}\right)$ and sulfite $\left(\mathrm{SO}_{3}{ }^{2-}\right)$ species. This in turn further complicates the handling of sulphide surfaces, since no univocal model surface can be adopted, being the chemistry ruled by several further parameters, both 
in the solid/gas phase (i.e., nanoparticles exposed to air) or in the liquid/solid phase (i.e., suspensions of nanoparticles).

The surface properties of bulk transition metal sulphides are best discussed by classifying the compounds according to the bulk structure. The discussion can be started by examining the case of transition metal monosulphides, which generally prefer hexagonal structures, viz. the NiAs structure, adopted by NiS and FeS. ZnS can also be found in nature in a hexagonal structure, namely wurtzite, but attention is now focused on the most typical sphalerite case, which is a cubic structure. As it is usual for all II-VI semiconductors, the most stable and abundant surface is the (110) one $[164,171,172]$. Surface relaxation essentially involve inward and outward displacements of cations and anions, respectively. The stability of the (110) surface is reflected in the theoretical equilibrium shape of the ZnS crystal. In fact, the minimization of the surface Gibbs free energy as performed in the Wulff construction, generates a dodecahedron exposing only (110) facets [171], as shown in Figure 2.

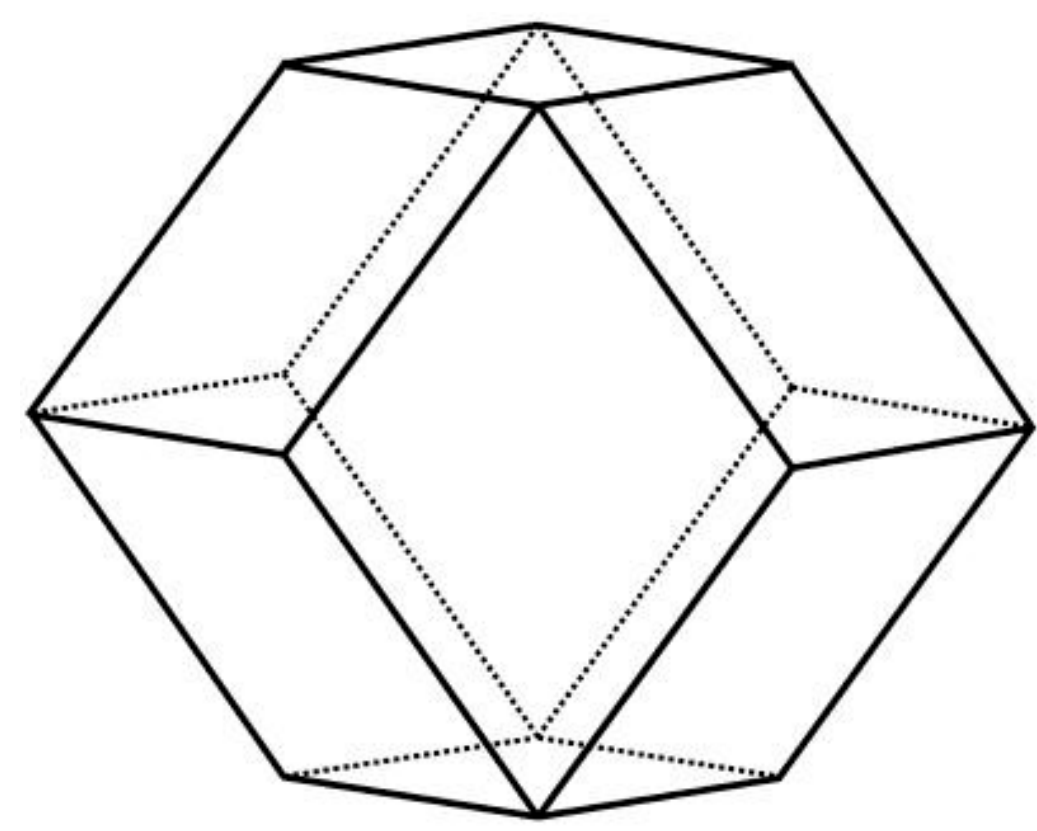

Figure 2. Calculated morphology of the cubic phase of $\mathrm{ZnS}$, as obtained by relaxed surface energies. The only surface to appear is the (110). Taken from Ref. [171]. Copyright American Chemical Society.

Experimentally, other surfaces are also observed, including the non-polar ( $\overline{4} 31)$ and (431) surfaces and the polar (111) surface. The (111) surface, both cation- and anion-terminated, is in principle unstable, being a type III surface for the Tasker rules [173]. However, the macroscopic electric field perpendicular to the surface can be compensated by suitable stoichiometric defects. Particularly favoured is the formation of vacancies in the terminal cation/anion layers [171]. The surface properties of FeS in the troilite structure has been studied by Wells et al. [174]. Only the (100) surface was considered, finding that it tends to reconstruct in such a way to form triangles of iron atoms "capped" with a sulphur atom.

The case of layered disulphides, which contain monoatomic $S$ anions, and that are formed by the early transition elements of each period (e.g., $\mathrm{TiS}_{2}, \mathrm{MoS}_{2}$ ) is a peculiar one. As it is common for layered compounds, the (001) surface is very stable and practically inert, so that most interest has been devoted to the so-called "edge surfaces", which terminate the $\mathrm{MoS}_{2}$ nanoribbons. In general, these edge surfaces are characterized by strong rearrangements due to the breaking of S-S bonds. After the pioneering work by Raybaud et al. [168] the $\mathrm{MoS}_{2}$ edge surfaces have been systematically studied and compared theoretically by Spirko et al. [175], Figure 3. 


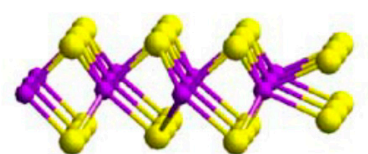

$(10 \overline{1} 0) \mathrm{b}$

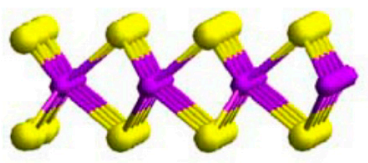

$(10 \overline{1} 0) \mathrm{a}$

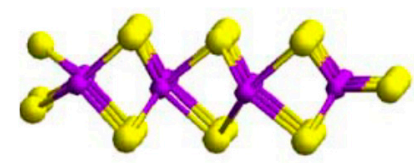

$(10 \overline{1} x)$

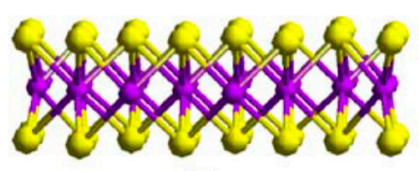

$(1 \overline{2} 10)$

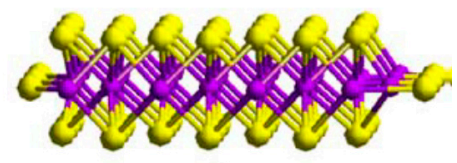

$(1 \overline{2} 1 x)$

Figure 3. Side views along the relaxed $\mathrm{MoS}_{2}$ edges rearrangement. Taken from Ref. [175], with permission by Elsevier.

The most stable are the (1010) "diagonally" cut in such a way to include half of the terminal $\mathrm{S}$ ions, followed by $(1 \overline{2} 10)$ edges cut in an analogous way. These diagonal cuts allow an efficient reconstruction, which substantially lowers the system energy.

Disulphides of late transition elements are characterised by the presence of $\mathrm{S}_{2}{ }^{2-}$ ions, and may be observed in rock-salt (pyrite), rutile (marcasite) and in the arsenopyrite structures. Particular attention has been devoted to $\mathrm{Fe}(\mathrm{II})$, compounds, such as chalcopyrite $\mathrm{CuFeS}_{2}$ and pyrite $\mathrm{FeS}_{2}$. The most common natural surfaces of $\mathrm{FeS}_{2}$ are the (100), (110), (111), and (210) ones. The stability as well as the structural and electronic properties of these surfaces have been investigated by first principles calculations by Hung et al. [176]. Ion relaxations are generally weaker than in the above examined cases, which is explained by the rock-salt structure of pyrite. However, reconstruction such as micro-facetting has been theoretically predicted to be relevant, and able to make the (110) surface even more stable than the (100) one. In general, apparent relationship between overall surface Fe coordination and surface energy, with the presence of lower-coordinated species resulting in higher dangling bond density and therefore higher energy, less stable surfaces, are evidenced.

Among disulphides, $\mathrm{MoS}_{2}$ is interesting both as a hydro-treating and as a desulphurisation catalyst. The complicated chemistry of its edge surfaces has stimulated several theoretical and experimental investigations [177-182]. More systematic studies involving a broader range of metal sulphides [183] are also reported. These studies allowed to prove, through the use of Sabatier analysis, that Co and Ni almost optimally promote the catalytic activity of $\mathrm{MoS}_{2}$ by weakening the HS binding energy. As pointed out above, the basal (001) surface of $\mathrm{MoS}_{2}$ is generally considered to be inert. Very recently, however, it has been pointed out that a careful combination of strain and S-vacancies can greatly enhance the activity of $\mathrm{MoS}_{2}$ for the hydrogen evolution reaction, as predicted by theoretical calculations [184]. The surface of $\mathrm{MoS}_{2}$ has also been the topic of detailed FT-IR studies [185,186].

As one of the chosen model systems, $\mathrm{ZnS}$ crystals undergo surface modification by reacting with the environment. By studying several samples composed of sphalerite and/or wurtzite ZnS crystals, Hertl [38] has hypothised the presence of -OH and -SH groups and of molecularly adsorbed water as well as a significant surface oxidation, revealed by the presence of sulphite and sulphate species.

In a further study on the high temperature $(823 \mathrm{~K}$ ) reaction of water vapour with the $\mathrm{ZnS}$ surface, mainly sulphite and additionally adsorbed water, hydrogen sulphide and adsorbed sulphur oxides were detected by FT-IR analysis. Exposure to oxygen determined the formation also of sulphate species [187]. In a very comprehensive experimental and computational study by Balantseva et al. [164], a combined theoretical and experimental work was carried out to unveil details on the $\mathrm{ZnS}$ surface 
chemistry. ZnS nanoparticles were prepared by an easy precipitation method and activated in vacuum in order to clean the surface without affecting the stability of the cubic $\mathrm{ZnS}$ phase. The results were also compared to those of a commercial bulk ZnS sample (particle size $<10 \mu \mathrm{m}$ ). The combined approach allowed to evidence as the strength of $\mathrm{Zn}^{2+}$ Lewis acidity in $\mathrm{ZnS}$ is considerably lower than in $\mathrm{ZnO}$ and more comparable to those of other oxides like $\mathrm{TiO}_{2}\left(\Delta \mathrm{E}_{\mathrm{ads}}=-0.22 \mathrm{eV}\right)$ and $\mathrm{MgO}\left(\Delta \mathrm{E}_{\mathrm{ads}}=-0.11 \mathrm{eV}\right)$ as well as the surface Lewis acidity of $\mathrm{Zn}^{2+}$ sites in $\mathrm{ZnS}$ nanocrystals appears significantly different with respect to the same sites in bigger microcrystals. The paper also outlines as, though the intense research activity on the synthesis and properties of nanostructured $\mathrm{ZnS}$ materials, very little information is available about their surface structure, which however can play an outstanding role in controlling ZnS crystal growth. This includes the presence of defects or disorder and of surface ligands or adsorbed species, which can determine important properties, including optical absorption threshold position and photoluminescence efficiency. Furthermore, a description of the surface from an atomic point of view could be crucial for a thorough understanding of photocatalytic processes.

Concerning iron, the surface reactivity of $\mathrm{FeS}_{2}$ has been studied in UHV by several authors, with contrasting results. This has been ascribed to the difference between pyrite surfaces obtained by crystal fracturing and those grown and cleaned in vacuum. In fact, whereas the former is found to react with $\mathrm{O}_{2}$ [188], the latter is non-reactive [189-191]. Arsenic is a common contaminant of pyrite, which may rise concerns about the environmental impact of this mineral. DFT calculations however show that there is no tendency for As impurities to segregate at the surface [192].

Focusing instead on nanocrystals, a very exciting class of systems $[36,41,50,139,150,193-247]$ in which the relevance of surface becomes important and the properties transition with respect to the bulk is particularly noticeable $[208,241,248,249]$, their surface chemistry has been the topic of extensive research and contributions, mostly on oxide NCs [36,41,50,202,209,210,215,219,221,222,240,246,250-260]. Little attention has been instead paid to sulphide NCs, though some contribution focus on both their synthesis [261-267] as well as on their surface chemistry [152,262,268-273].

Concerning the main differences with respect to the oxide counterparts, sulphides are typically cation-rich, which enhances the adsorption of, inter alia, negatively charged carboxylates. Conversely, the homologue oxides are typical stoichiometric and have dissociatively adsorbed carboxylic acids on their surface [251]. In this regard, in a study by Hens et al. [274], the ligand composition and dynamics of monodisperse suspensions $\mathrm{PbS}$ quantum dots was effectively investigated with nuclear magnetic resonance (NMR) spectroscopy. This study evidenced how oleate ions strongly bind to the cation-rich surface of the sulphide. The ligand exchange and the stoichiometry of metal chalcogenide nanocrystals were spectroscopically investigated outlining an easy metal-carboxylate displacement and binding [211]. In particular, the authors demonstrated as metal carboxylate complexes $\left(\mathrm{L}-\mathrm{M}\left(\mathrm{O}_{2} \mathrm{CR}\right)_{(2)}\right.$, $\mathrm{R}=$ oleyl, tetradecyl, $\mathrm{M}=\mathrm{Cd}, \mathrm{Pb}$ ) are readily displaced from carboxylate-terminated metal chalcogenides $(\mathrm{ME})$ nanocrystals $(\mathrm{ME}=\mathrm{CdSe}, \mathrm{CdS}, \mathrm{PbSe}, \mathrm{PbS})$ by various Lewis bases, the relative displacement efficiency being assessed by ${ }^{1} \mathrm{H}$ NMR spectroscopy and being strongly dependent on geometric factors such as steric arrangement and chelation. The results presented in the cited work suggest as ligands displace $\mathrm{L}-\mathrm{M}\left(\mathrm{O}_{2} \mathrm{CR}\right)_{(2)}$ by cooperatively complexing the displaced metal ion as well as the nanocrystal. The results demonstrate that nanocrystals cannot be defined by a single chemical formula, but are instead better described as dynamic structures with concentration-dependent compositions. The presented outputs are noticeable, since they have a relevant importance for the synthesis and purification of nanocrystals as well as ligand exchange reactions.

De Roo et al. [250] highlighted as NCs might also serve as suitable model systems to understand the interaction of organic molecules with macroscopic, inorganic material, e.g., solid-state membranes or mesoporous materials and they can also effectively used as model systems can also be used to revisit existing theories of NC nucleation and growth. 


\subsection{Nanocrystal-Ligand Interactions and Ligands Exchange Dynamics}

Manipulating and tailoring nanocrystal surface ligands is a crucial step for their practical application as optoelectronic devices and fluorescent labels for biological imaging. The ligand exchange between the existing ligand and a new one is generally based on a two-step stripping route in which the existing ligand is replaced by the new once, typically displaying higher affinity and stronger binding to the targeted surface. Ligand exchange $[6,195,211,222,240,251,255,275-284]$ is required to replace insulating organic surfactants and allow charge transport in nanocrystal solids as well as to prepare water-soluble nanocrystals that target specific cellular sites.

In an interesting contribution on shape-control through tailoring of surface-ligand interactions, Hennig [214] et al. outline as a deep understanding of NC surface chemistry is increasingly recognised to be critical for the comprehension of a broad range of phenomena and issues, including charge transport, solubility, functionalisation (e.g., for biological systems), optical properties (e.g., quantum yield), and the assembly of NCs into ordered super-structures and arrays [208,285,286]. Unravelling the effect of ligands on the NC properties and behaviour is better accomplished through atomistic computational methods, whereas it can be hardly pursued through standard analytical tools, typically more suited for the characterisation of well-defined planar interfaces. The NC shape is eventually controlled by the thermodynamics and growth kinetics of the dynamic system composed of the inorganic core, the ligands, and the solution containing both NC chemical precursors and ligand species. In this case, DFT calculations allowed to determine surface and binding energies for PbSe $\{100\}$ and reconstructed $\{111\}$ surfaces, capped with $\mathrm{Pb}\left(\mathrm{OAc}^{-}\right)_{2}$ for a range of coverages. The authors of these studies concluded as, through the consideration of the surface/ligand interactions in the PbSe NC system, a model can be obtained. This model allows to predict that the facet-dependent interactions between core and ligand capping layer can be exploited, through the variation of the ligand concentration, to control the morphology and shape evolution not only of single NCs, but also of their assembly.

As outlined by some authors, as for instance the quoted work by Hens et al. [253], ligand exchange approaches are valuable tools to (i) adjust the interaction of the NC with their environment for instance modulating their solubility in either polar or apolar solvents; to (ii) enable the use of NC as biolabels, bioimaging probes or biosensors, through exchange with biomolecules; or to (iii) pursue the assembly of NC arrays, by replacing the original monofunctional ligand with bi- or polyfunctional ones.

To this aim, the understanding of NC-ligand interactions is mandatory also to develop successful ligand exchange strategies. In this framework, the NC-ligand exchange can also be effectively be followed by solution NMR, as extensively reported by Hens and Martins [253], also by using an in situ approach. For instance, in the case of oxides, in particular hafnia [251] surface chemistry of $\mathrm{NC}$, has been studied through a multitechnique approach encompassing different NMR methods (Nuclear Overhauser Effect Spectroscopy (NOESY, Diffusion Ordered Spectroscopy (DOSY)) and FT-IR spectroscopy.

In a contribution by Mews [255], the ligand exchange on NC surface was investigated by Fluorescence Resonance Energy Transfer (FRET). In this study, the NC-ligand interaction was proven to influence the electronic properties of the NCs and also fluorescence in semiconductor NCs due to the weak binding of ligands. In fact, exchange with different polymeric ligands showed to influence not merely the colloidal stability, but also the fluorescence quantum yield. Furthermore, the strength of the binding was found to be enhanced by multi-dentate ligands, in that specific case amines.

Again concerning ligand dynamics, Owen and coworkers demonstrated that the surface layer of excess metal ions is labile and reversibly binds to and dissociates from nanocrystal surfaces as carboxylate complexes $\left(\mathrm{M}\left(\mathrm{O}_{2} \mathrm{CR}\right)_{2}\right)$; denoted as a Z-type ligand. They also adopted a rational ligand labelling, based on the covalent bond classification method developed by M. L. H. Green [287], in which L-type ligands are two-electron donors (neutral Lewis bases, dative covalent bonds), X-type ligands are one-electron donors (anionic, normal covalent bonds), and Z-type ligands are two-electron acceptors (Lewis acids). 
$\mathrm{PbS}$ colloids have been used by Giansante et al. [252] to investigate the dynamics at organic/ inorganic interfaces (Figure 4).

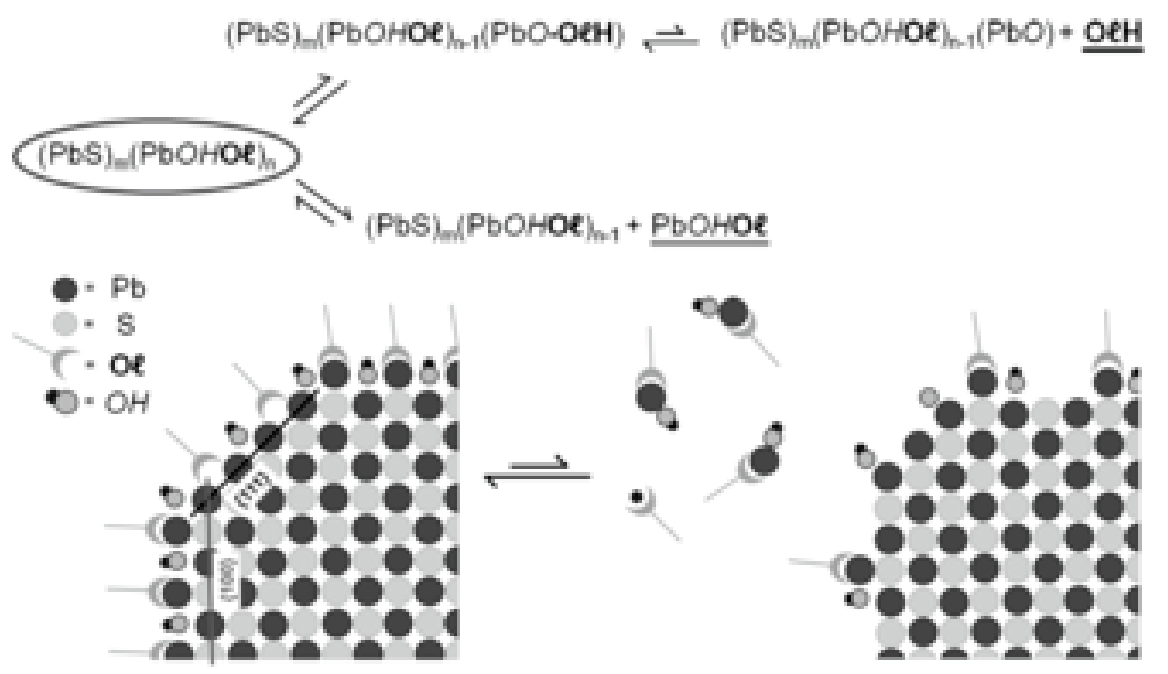

Figure 4. Simplified chemical formula of colloidal PbS Quantum Dots (QDs) and schematic representation of the dynamic equilibria involving oleic acid $(\mathrm{O} \ell \mathrm{H})$ and $\mathrm{Pb}$ oleate $(\mathrm{PbOHO} \ell)$ as ligands at the $\{111\}$ and $\{100\}$ facets of the QD. Taken from Ref. [252] with permission of Wiley VCH.

It turned out that the organic/inorganic interface markedly affects forms and functions of the quantum dots, therefore its description and control are important for effective application. The authors showed that model sulphide NCs, i.e., PbS colloids, adapt their interface to the surroundings, thus existing in solution phase as equilibrium mixtures with their (metal-)organic ligand and inorganic core components. The interfacial equilibria are ruled by solvent polarity and concentration, show striking size dependence (leading to more stable ligand/core adducts for larger quantum dots), and selectively involve nanocrystal facets. The understanding of this ligand/core dynamic equilibrium is relevant not only to develop new synthetic paths but also to implement successful functionalisation and surface-chemistry strategies.

In the study of the interplay between the organic ligand shell and the inorganic core, magic-sized clusters [288], which are predominately surface atoms, provide a promising tool to clarify these critical surface interactions. This model system has been used to unveil the complex interactions ruling the surface chemistry of cadmium sulphide nanoparticles. These interactions affect the surface of both nanoparticles and magic-sized clusters and the results presented by Douglas et al. highlight the utility of the clusters as a probe of ligand-surface interactions.

The covalent bond classification has been also adopted by Van Driessche, De Roo et al. [250] to rationalise and classify in a logical fashion different binding motifs. The model additionally allows to effectively predict and to rationalise ligand exchange and ligand displacement reactions, therefore disclosing new applications for NCs in the field, inter alia, of opto-electronics, photovoltaics and catalysis, to mention the most relevant ones. Although the surface chemistry of several semiconductors and metal oxide nanocrystals are currently well-understood, more efforts are needed to unravel the ligand-NC interactions in the other materials. In fact, the general approach has been so far chiefly applied to oxides, but its adjustment and application to sulphides can be envisioned.

Ligands can be also used to direct the growth of the forming NCs [289-292]. In the ligand-assisted growth of NCs, the surface ligand dynamics is affected by the growth temperature, the ligand concentration and the ligand chain length, as outlined by Peng et al. [240], and as shown in Figure 5. Also the intermolecular interactions among the ligands can affect the growth of the NCs. These complex dynamic phenomena have been proven to influence also the final shape and morphology on the resulting colloids. 

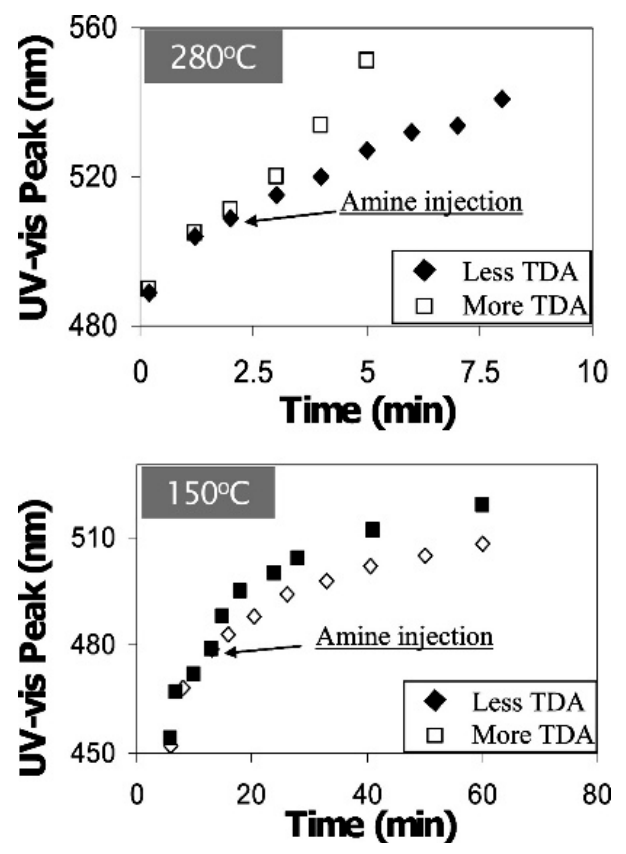

Figure 5. Impact of tetradecylamine (TDA) concentration on the growth of CdSe nanocrystals at $280{ }^{\circ} \mathrm{C}$ (above the bp for TDA) (top plot) and $150{ }^{\circ} \mathrm{C}$ (below the bp of TDA) (bottom plot). Taken from Ref. [240] with permission of the American Chemical Society.

Surface chemistry additionally rules the self-assembly behaviour of NCs, which can be used to obtain NC superlattices. In fact, as outlined by Hanrath and coworkers [214], the assembly of colloidal nanocrystals (NCs) into superstructures with long-range translational and orientational order is sensitive to the molecular interactions between ligands bound to the NC surface. In their study (see Figure 6, referring to the equilibrium form), the authors show as ligand coverage on colloidal PbS NCs can be exploited as a tunable parameter to direct the self-assembly of superlattices with given symmetry.

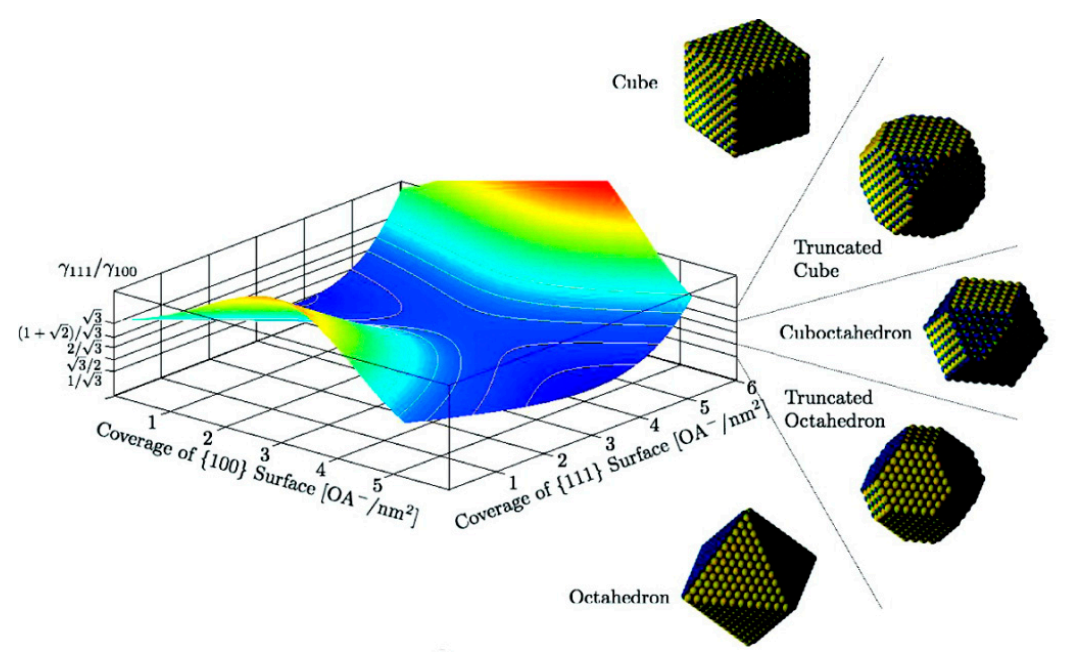

Figure 6. Surface energies and equilibrium shape of PbSe NC as a function of surface coverage with oleic acid molecules. (a) Ratio of the surface energies $\gamma 111 / \gamma 100$ as a function of the coverages of the $\{100\}$ and $\{111\}$ surfaces. The ratios $\gamma 111 / \gamma 100=\sqrt{ } 3,(1+\sqrt{ } 2) / \sqrt{ } 3,2 / \sqrt{ } 3, \sqrt{ } 3 / 2$, and $1 / \sqrt{ } 3$ are plotted as contours on the surface and correspond to NC cores with the equilibrium shape of a cube, uniform truncated cube, cuboctahedron, uniform truncated octahedron, and octahedron, respectively. Adapted from Ref. [214] with permission of the American Chemical Society. 
The study additionally evidenced how the interplay of different analytical and theoretical tools is effective in thoroughly characterising these complex supramolecular systems. In particular, surface chemistry characterization encompassing FT-IR, XPS and Grazing Incidence SAXS (GI-SAXS) combined with density functional theory calculations suggest that the loss of ligands occurs preferentially on $\{100\}$ than on reconstructed $\{111\}$ NC facets.

\subsection{Applications-Oriented Functionalisation of Transition Metal Sulphides}

Most metal sulphides, in analogy with the oxide counterparts [63], feature exciting as well as diverse chemico-physical properties. Their electric behaviour ranges from insulating, through semiconductive to metallic. Likewise, they can be diamagnetic, paramagnetic, ferromagnetic or antiferromagnetic [1,44,293-296]. A relevant functional property displayed by some metal sulphides, particularly upon doping, is luminescence [46], which is broadly used also in optical bioimaging applications of these compounds $[1,10,44,297-300]$. Sulphide-based luminescent materials have attracted much attention for a wide range of photo-, cathodo- and electroluminescent applications. Upon doping with lanthanides or transition metal ions such as $\mathrm{Mn}^{2+}$ or $\mathrm{Cu}^{2+}$, the luminescence can be tuned over the entire visible region by appropriately choosing the composition of the sulphide host. Among the wide range of applications, flat panel displays based on electroluminescent thin film, field emission displays and ZnS-based phosphors [46,262,301,302] and electroluminescent powders for backlights are worth to be mentioned.

By exploiting their interesting optical and electronic properties, transition metal sulphides can be used additionally for the development of devices in electronic and energy applications, in which the surface functionalisation of nanoparticles with specific ligands are relevant to ensure the charge transport properties of nanoparticles arrays.

In this regard, a novel and fascinating approach for the post-functionalisation of nanocrystals, among which also metal sulphide colloids, is based on the use of inorganic ligands [279]. In particular, various inorganic anions including metal-free chalcogenides, oxoanions/oxometallates, and halides/ pseudohalides/halometallates have been employed to replace the original long-chain organic ligands on NCs. These ligands, with respect to single NC functionalised with insulating organic ligands, can passivate surface traps, are electronically transparent and can enhance the interparticle charge transport. This approach based on inorganic ligands broaden the functionality of NCs by tailoring their electro-optical properties or generating new inorganic phases through chemical reactions between nanomaterials and their surface ligands. Especially promising are the electronic, optoelectronic, and thermoelectric applications of solution-processed and inorganically-capped colloidal NCs, which substantially outperform their organically-capped counterparts.

A further example reported in the literature [16] and again involving cooperative effects, is instead concerned with absence of ligands in inorganic nanocrystals designed to exhibit negative charges and, therefore, electrostatically stabilised to give a colloidal dispersion in polar solvents. Undoped and $\mathrm{Mn}$-doped $\mathrm{Zn}_{\mathrm{x}} \mathrm{Cd}_{1-\mathrm{x}} \mathrm{S}$ nanocrystals were studied, the latter showing strong luminescence. Also in this case, the possibility of surface-mediated electronic coupling between ligand-free sulphide nanocrystals was evidenced, which make them more suitable for electronic and optoelectronic applications compared to organic-capped nanocrystals.

The luminescent properties, combined with low or absent cytoxicity $[158,299]$, (except for cadmium chalcogenides, broadly used as luminescent quantum dot [20,258,303-311]), make transition metal sulphide appealing candidate probes for optical bioimaging applications and further related bio-applications (e.g., photothermal and/or photodynamic applications [10,312,313]). As we shall extensively discuss in the next section, all these applications require a chemical, photochemical and thermal stable functionalisation. Nevertheless, they are not the only applications requiring functionalisation. Dispersions of transition metal sulphide nanoparticles in liquid media can find wide applications as precursors for nanocomposites or films with tailored functional and structural properties [140,314,315], or for stable suspensions for inks and paints. 
Whereas in the cases of metallic and metal oxide nanoparticles (NPs) well-established and reliable functionalisation protocols have been developed and optimised (see the most remarkable reactions listed in Figure 7) [220,276,316-318], the development of effective surface-derivatisation methods for metal sulphide-based analogues has not been fully met so far by synthetic chemists, and reports retrieved in the literature fail, in several cases, either to convincingly demonstrate the stable functionalisation of metal sulphides or to prove the actual chemical nature of the sulphide surface, as also outlined by other authors $[164,172]$.

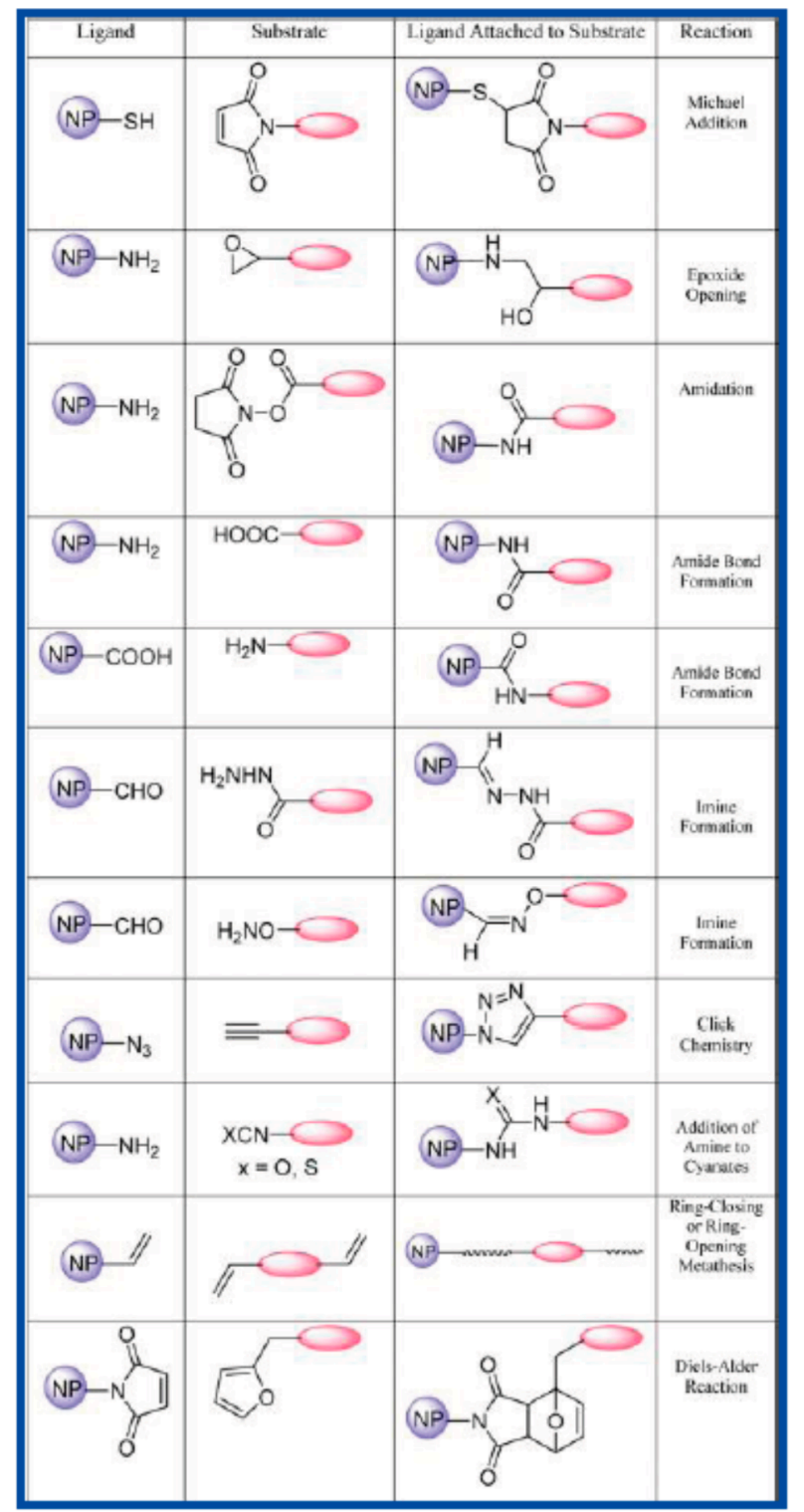

Figure 7. Functionalisation strategies for inorganic nanoparticles. Reprinted with permission from Ref. [318]. Copyright 2012 American Chemical Society.

The functionalisation strategy for an inorganic colloid is tightly related to the nature of the colloid, and hence to the synthetic route chosen to prepare it. Inorganic colloids and nanoparticles can chiefly be approached by two main strategies, involving either (i) hydrophobic conditions or (ii) direct synthesis in aqueous phase, resulting in hydrophobic and hydrophilic colloids, respectively. Several colloidal-based methods are based on the use of surfactants, which yield the formation of stable particles and/or emulsions, therefore these methods deliver nanoparticles which are inherently 
hydrophobic, causing insolubility in water and preventing further functionalisation. However, since stable water dispersions are mandatory for many applications, ranging from bio-oriented ones to inks and paints production, functionalisation is a key step prior to the applications of NPs. Effective derivatisation chemistry becomes therefore critical toward colloidally stable, water-soluble NPs with flexible surface chemistry. The robust, steric stabilisation of inorganic nanocolloids within aqueous and physiological media via an appropriate chemical functionalisation stands as a fundamental requirement to enable their application in the biomedical field, particularly for the designing of novel bioimaging systems.

In the literature, hundreds of different functionalisation approaches are reported. They can be classified starting from the nature of chemical reactions involved, as reported in Figure 7, or they can be more easily sorted into three general typologies [220,276,316-318]:

(i) direct encapsulation of the hydrophobic NPs by hydrophilic polymers [289,319,320],

(ii) ligand exchange of the original surfactant with hydrophilic ligands [211,222,275-277,280,281,283, 320,321],

(iii) formation of an interdigitated bilayer between amphiphilic molecules or polymers and the passivating surfactant layer on the NP surface.

It should however be highlighted that the general functionalisation strategies reported in Figure 7, could be applicable to any suitable inorganic system, either metal sulphides or oxides, once the nature of the interacting moieties on the surface is identified or speficifically provided within a previous derivatisation step.

Among the most employed ligands for metal nanoparticles, thiols [39,322-328] have to be mentioned, whereas metal oxides NP can be conveniently derivatised by carboxylates or, even stronger, by multifunctional ligands such as dopamine-derivatives and cathecols [280,283,292,329-331]. A further distinction can be carried out accordingly to the chemical nature of the surface to be derivatised, which can be noble metal NPs $[9,141,163,269,318,332-368]$ or metal oxides, the most commonly functionalised colloids, but also of other composition (halogenides, chalcogenides, phosphates, carbonates etc.).

Viable strategies to functionalise a nanostructure may also be classified depending on the interaction between ligand and surface, being either covalent (or coordinative) and non-covalent. The former, also based on multifunctional molecules, have enabled the development of stable systems also in harsh conditions such as extremely low (1) or high (14) pH values [369]. The latter discloses instead the possibility to apply rapid and easy self-assembly procedures involving the inorganic substrate and the organic ligand.

As far as the most explored application field is concerned, i.e., biomedicine, the robust, typically steric stabilisation of inorganic colloids within aqueous and physiological media via an appropriate chemical functionalisation stands as a fundamental step to enable their application, particularly for the design of novel bioimaging systems.

Surface derivatisation for bioimaging purposes of inorganic fluorophores is typically pursued by chemisorptions of selected molecules, which convey, with respect to physisorption, more robust bond and more stable surface functionalisation, hence ensuring an effective bioconjugation. The use of inorganic NP as fluorophores is motivated by different reasons. Compared to the homologue organic fluorescent dyes, inorganic colloids are endowed with better performances and stability. In fact, by combining suitable semiconductor nanocrystals with biomolecules it is possible to prepare new advanced systems with enhanced resolution and specific fluorescence detection capability $[1,125,276,346,370,371]$. Commonly used organic fluorophores have two significant limitations: (1) they cannot fluoresce continuously over long periods (long term imaging) and (2) they are not optimised for multicolour applications (multiplexing) [372], i.e., simultaneous, not sequential, detection of multiple signals. The unique optical properties of inorganic colloids, in many case referred to as Quantum Dots (QD) [20,39,44,46,163,210,307,311,373-377], make them instead appealing 
as in vivo and in vitro fluorophores in a variety of biological investigations because they are able to overcome problems of long-term stability and multi-signal detection [105,372,378]. Nevertheless, one of the most significant drawbacks is the toxicity of QDs. Among QD, increasingly used are metal sulphides, characterised by low or absent toxicity such as ZnS [299,300].

\section{Functionalisation of Transition Metal Sulphides: Case Studies}

In this section, selected transition metal sulphides were chosen (i.e., $\mathrm{ZnS}, \mathrm{Cu}_{\mathrm{x}} \mathrm{S}(\mathrm{x}=1,2), \mathrm{Fe}_{\mathrm{x}} \mathrm{S}_{\mathrm{y}}$ $\left.(x=0,1,2 ; y=2,3), M_{2}\right)$ to describe the manifold possibilities to address the functionalisation of these peculiar surfaces. The choice was driven mostly by three factors:

i relevance and wide applicability of the sulphide;

ii broadest differences among the chemistry, the structural and electronic features of the selected sulphides;

iii broadest differences among the chemistry and the structural features of the selected ligands as well as of their interaction with the sulphide surface.

CdS was deliberately not considered, due to the well-known toxicity, limiting its applications in bio-related fields. References on CdS nanoparticles are provided for interested readers $[49,265,306,307$, 310,379-385].

In the following, the different sulphides substrates are concisely described, and an overview of their most relevant surface features is provided. The following section of each paragraph outlines instead the state-of-the-art relative to the selected examples concerning their functionalisation.

\subsection{Zinc Sulphide}

Among the metal sulphides, zinc sulphide $(\mathrm{ZnS})[8,33,38,386]$ is one of the most investigated. It has been especially studied because of its appealing electronic properties, i.e., a wide band gap $(3.7 \mathrm{eV})$ and a high exciton binding energy $(40 \mathrm{meV})$. Zinc sulphide is among the most appealing semiconducting materials for the development of electroluminescent devices [46,301,387], which enables the direct conversion of electric energy into visible light, without generating heat, or requiring chemical or mechanical triggers. Additionally, ZnS can be easily doped by multiple ions (multiplexing), making it a suitable starting material for the development of optical and optoelectronic devices. Its intrinsic luminescence and the possibility of easy doping disclose its application in optoelectronics and related fields [8]. Moreover, it is environmental friendly and not-cytotoxic [298,299], thus suggesting possible applications also in biomedicine. In fact, combining the biocompatibility and the luminescence, optical bioimaging applications can be pursued [298,299]. For all these reasons and thanks to ZnS non-toxicity and intrinsic photoluminescence, ZnS NPs can be envisioned as high-performance and biocompatible bioimaging probes, although their stable dispersion in aqueous media still remains an open challenge, as discussed in the following.

The phase diagram defining the conditions of existence of the different polymorphs (sphalerite and wurtzite being the most relevant ones) has been obtained and reported along with main thermodynamic and structural data on the compound [388], whereas the pressure-induced structural changes in $\mathrm{ZnS}$ have been investigated by Desgreniers et al. [389].

Surface effects in ZnS are particularly interesting: Banfield et al. [273] have outlined as, whenever the surface of a $\mathrm{ZnS}$ nanoparticle gets wet, the whole crystal structure rearranges to become more ordered, closer to the structure of bulk ZnS. The same authors reported [390] that very small zinc sulphide nanoparticles display a disordered crystal structure that puts them under constant strain, increasing the stiffness of the particles. Surface chemical properties of zinc sulphide play a critical role in these phenomena. When zinc sulphide nanocrystals are put into water or either aqueous solution, surface hydration takes place, and the adsorption of proton and hydroxide ions make the surface either positively or negatively charged, in the absence of foreign preferentially adsorbed ions. Due to the sensitivity of sulphide ions to oxygen, redox reactions at the surfaces may occur as well. 
As also outlined in Section 2.2, the zinc sulphide surface is characterised by a rich chemistry, which is influenced by the overall equilibrium of surface and solution chemical reactions, encompassing redox, acid-base, surface complexation, precipitation and dissolutions [271]. A comprehensive list of all possible occurring reactions is reported in ref. [271], which collects relevant chemical reactions and corresponding equilibrium constants, as retrieved from a comprehensive literature on the topic. The interplay of all these equilibria involving sulphides, hydrogensulphides, sulphates, is obviously determined by $\mathrm{pH}$, concentration and different reactions can occur simultaneously in dependence of these factors. Based on this complex coexistence of equilibria, E-pH diagram can be plotted (Figure 8), defining the boundary of existence of the different species, and outlining as, between $\mathrm{pH} 3-11$, when the concentration of $\mathrm{Zn}^{2+}$ and $\mathrm{S}^{=}$are equal, $\mathrm{ZnS}$ results the dominating species.

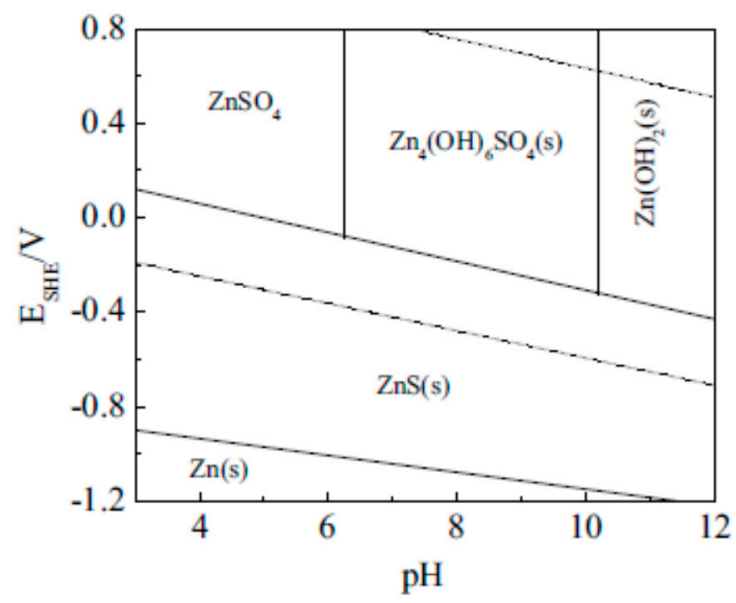

Figure 8. Predominant areas in E-pH diagram in $\mathrm{Zn}^{2+}-\mathrm{HS}^{-}$and $\mathrm{H}_{2} \mathrm{O}$ system $\left(\mathrm{Zn}^{2+}=0.1 \mathrm{M} ; \mathrm{HS}^{-}=0.1 \mathrm{M}\right)$. Reprinted with permission from Ref. [271]. Copyright 2011 Chemistry Central Journal.

The same paper discusses further, based on potentiometric titration, adsorption and solution speciation modelling, the nature of the ZnS surface. Surface acidity, surface stoichiometry and surface proton binding sites are thoroughly analysed. The results show that, for stoichiometric surfaces of zinc sulphide, the proton and hydroxide determine the surface charge, whereas for the nonstoichiometric surfaces, the surface charge is controlled by proton, hydroxide, zinc and sulphide ions depending on specific conditions. Analogously, a distribution of the different species as a function of relative concentrations and $\mathrm{pH}$ is provided in the same paper (Figure 9). These are all aspects of the surface chemistry to be taken into account when planning an effective functionalisation. At the same time, this data evidences how complex and multifaceted is the surface chemistry of this sulphide. An important conclusion of the mentioned paper is that the surface stoichiometry strongly affects the surface properties of zinc sulphide; either zinc rich or sulphur rich surface determine different acid base properties, i.e., different surface acidity constants, ruling also the kind of functionalisation strategy to be implemented.

Nevertheless, a comprehensive, systematic and unambiguous characterisation of the precise surface composition of ZnS NPs (following the diverse synthetic pathways to obtain them) has not been provided so far, therefore hampering the identification of an effective functionalisation protocol and making the choice of a robust anchoring chemistry a challenging task. Although in several experimental and theoretical studies, it has been proposed that the $\mathrm{ZnS}$ surface could feature either oxidised species $\left(\mathrm{SO}_{4}, \mathrm{SO}_{3}, \mathrm{ZnO}\right)$ or reduced $(\mathrm{SH}, \mathrm{ZnOH})$ moieties [38], no unequivocal evidence of the chemical nature of these surfaces has been provided yet. Hence, a coherent proof of the selective ZnS surface-derivatisation by adsorbates presenting appropriate organic anchors remains still a partially unaccomplished issue in the recent literature. Additionally, it remains still open the question whether actually $\mathrm{ZnS}$ is the surface to be functionalised or rather partially or completely oxidised. 


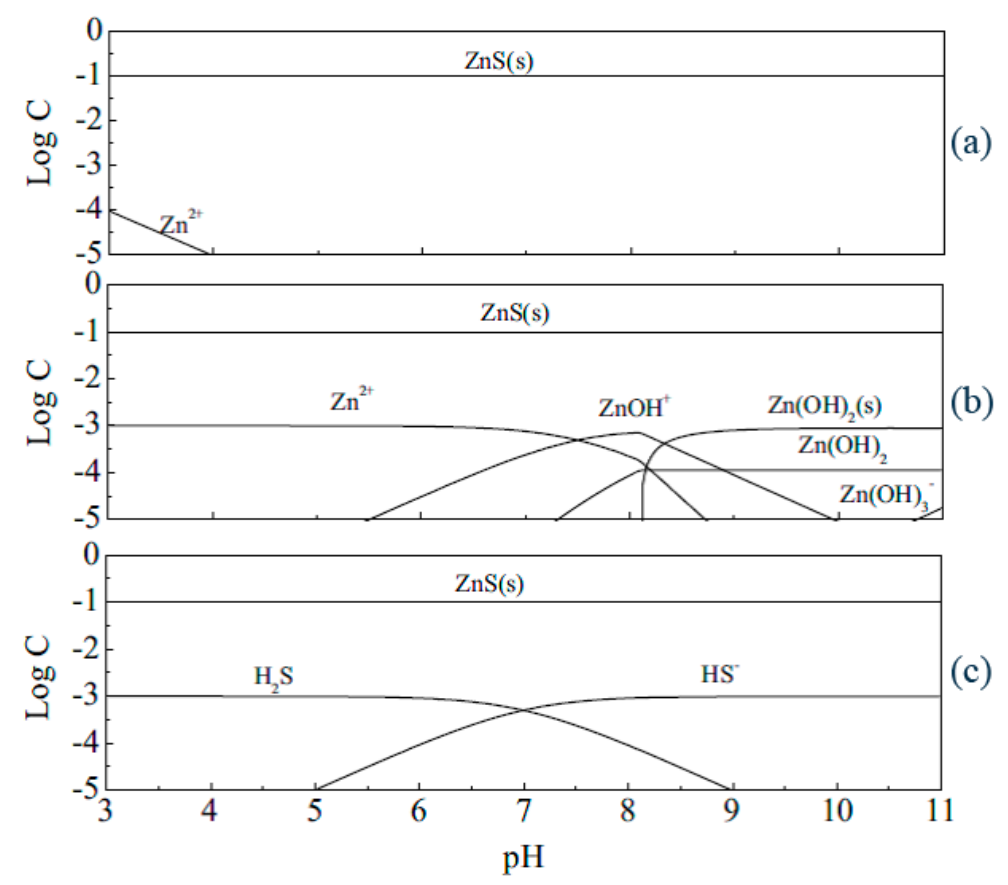

Figure 9. Distribution of zinc species in $\mathrm{Zn}^{2+}-\mathrm{HS}^{-}-\mathrm{H}_{2} \mathrm{O}$ system as a function of $\mathrm{pH}$ in the presence of: (a) $100 \mathrm{mM} \mathrm{Zn}{ }^{2+}, 100 \mathrm{mM} \mathrm{HS}^{-}$; (b) $101 \mathrm{mM} \mathrm{Zn}^{2+}, 100 \mathrm{mM} \mathrm{HS}^{-}$; (c) $101 \mathrm{mM} \mathrm{HS}^{-}, 100 \mathrm{mM}$ $\mathrm{Zn}^{2+}$.Adapted with permission from Ref. [271]. Copyright 2011 Chemistry Central Journal.

In the literature are however reported several examples of stable derivatisation of ZnS colloids, and hereafter some of the most meaningful ones are reported. Recently, the incorporation of $\mathrm{ZnS}: \mathrm{Mn}$ NPs into polymeric matrix (polyacrylic acid and polymethylmethacrylate) to convey luminescent properties to plastics was investigated [391-393], although no specific functions by the polymers were demonstrated to enhance the interactions with the NPs. Alternatively, semiconductor nanocrystals (entirely or partially constituted by sulphides) were successfully incorporated into polymeric matrices [394] or derivatised with oleic acid and hexadecyl- trimethylammonium bromide to allow their dispersion in organic phases. Also in these cases, no detailed description of the characteristics of the coated surface and a proof of the effective functionalisation were provided.

A further elegant route to surface-functionalized ZnS nanoparticles (NPs) to be embedded in polymer matrix was based on a facile ligand exchange approach of mercaptoethanol with 5-(2-methacryloylethyloxymethyl)-8-quinolinol (MQ) [278]. By exploiting in situ bulk polymerization, the functionalised MQ-ZnS NPs were successfully incorporated into the polymer matrix to fabricate transparent bulk nanocomposites with good thermal stability and processability.

In this case, different coordination modes of the ligand to the surface were proposed, as sketched in Scheme 1, and the ligand exchange as well as the coordination of MQ to the ZnS surface could be convincingly demonstrated by NMR.

Functionalisation of ZnS could be pursued also by hexamethylenetetramine [395], enhancing the optical properties and thermal stability of ZnS nanoparticles. In this case, by HR-TEM coupled with SAED, a convincing demonstration of $\mathrm{ZnS}$ cubic structure in very small (ca. $2 \mathrm{~nm}$ ) nanoparticles was provided. Therefore, the actual attachment of the hexamethylenetetramine on the surface could be inferred, probably mediated by the interaction of the amine group and the $\mathrm{Zn}^{2+}$ ions on the surface, as shown by FT-IR data. This latter was also evidencing Zn-S vibrations of the $\mathrm{ZnS}$ nanocrystals. A similar spectroscopic evidence is reported as a proof of successful functionalisation also in the paper of Taherian, where the S-H vibration of the thiol ligands glutathione and thioglycolic acid at $2550-2670 \mathrm{~cm}^{-1}$ is not observed anymore upon capping of the ZnS nanoparticles [396], therefore 
indicating successful anchoring of the ligand. In this study, the effect of ligand chemistry on the microstructural properties and photo-physical properties, in particular the UV absorption is discussed.

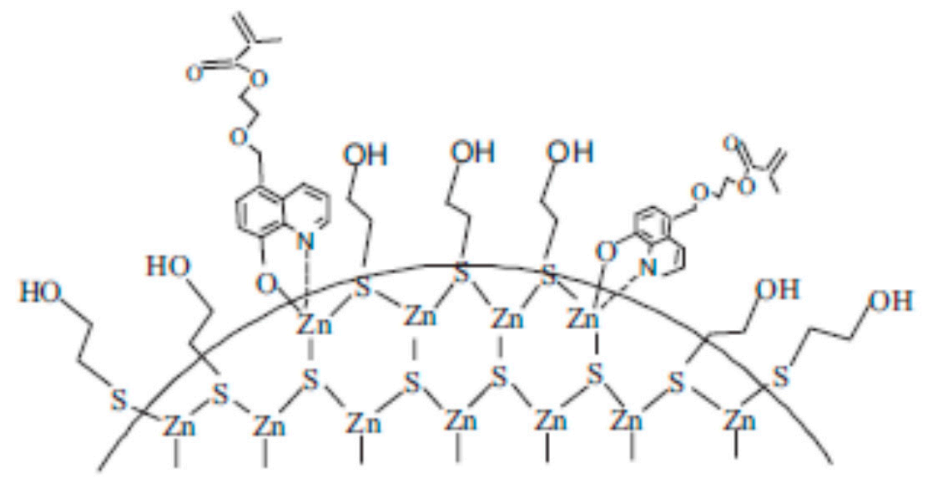

Scheme 1. Possible coordination structure of MQ on the surface of MQ-ZnS NPs. Reprinted with permission from Ref. [278]. Copyright 2008 Wiley VCH.

Folic acid (FA) conjugated carboxymethyl chitosan coordinated to manganese doped zinc sulphide quantum dot (FA-CMC-ZnS:Mn) nanoparticles for targeting, controlled drug delivery and also imaging of cancer cells was the topic of a comprehensive work of Mathew et al. [300]. The prepared nanoparticles were characterized using SEM, AFM, FT-IR, UV and DLS. Also in this further case, vibrational data were brought as demonstration of the successful occurred conjugation. Manzoor reported a further example of successful functionalization of $\mathrm{ZnS}$ with folic acid for targeted cancer imaging [299].

As a further example of functionalisation with folic acid, in another study [397], the synthesis of fluorescent-doped core/shell quantum dots of water-soluble manganese-doped zinc sulphide was addressed by a nucleation doping strategy, with 3-mercaptopropionic acid as stabiliser at $90{ }^{\circ} \mathrm{C}$ in aqueous solution. The manganese-doped zinc sulphide nanoparticles exhibit strong orange fluorescence under UV irradiation, resistance to photo-bleaching, and low-cytotoxicity to HeLa cells. In this case, the manganese-doped zinc sulphide nanoparticles were conjugated with folic acid using 2,20-(ethylenedioxy)-bis-(ethylamine) as the linker. The covalent binding of both 2,20-(ethylenedioxy)-bis-(ethylamine) and folic acid on the surface of manganese-could be probed by FT-IR detection.

Bioconjugation can be effectively accomplished by N-hydroxysuccinimide (NHS) chemistry. Generally, colloids prepared in non-aqueous medium need to be first solubilised in water through a ligand exchange reaction with thiol, amine, or carboxyl groups and then reacted with an $N$-(3-dimethylaminopropyl)- $N$ ethylcarbodiimide (EDC) and $N$-hydroxysuccinimide (NHS) pair to create reactive species of NHS-carboxylates to connect with the functional groups in the folic acid [398]. In the case of ZnS, a direct functionalisation with folic acid has been reported [399], by simply reacting $\mathrm{ZnS}$ with folic acid, in aqueous medium, at room temperature.

In several other reports, the functionalisation of ZnS NPs was achieved by means of adsorbates presenting cysteine functions, suggesting the formation of S-S linkages with the sulphur present on the NP surface, even though the study of the stability of the obtained suspensions was not addressed in these reports. In one of this, the development of biotin tagged avidin functionalised zinc sulphide nanocrystals through a simple aqueous chemistry route at room temperature for targeted imaging applications is reported [400]. Surface functionalisation of manganese doped $\mathrm{ZnS}$ nanocrystals with L-cysteine provided functional groups that facilitated its conjugation to avidin. Further biotinylation of these particles through the strong non-covalent interaction between biotin and avidin enabled highly specific labelling of the biotin receptors on human hepatocellular carcinoma cells.

Narayanaswamy and co-workers reported the synthesis of L-cysteine-capped ZnS QDs and used them for $\mathrm{Cu}$ detection [401]. Cysteine is a water-soluble amino acid and frequently used as a capping 
agent for ZnS QDs. The surface modification of ZnS QDs with cysteine prevents the aggregation of nanoparticles and makes them available for the interaction with the target materials. Furthermore, it increases the emission quantum yields of QDs and also stabilises the nanoparticles.

In a further paper [402], the authors report that $\mathrm{ZnS}$ nanoparticles were coated with a silica shell by exploiting the formation of $\mathrm{Zn}-\mathrm{O}-\mathrm{Si}$ bonds, as a result of the interaction of positively charged $\mathrm{Zn}^{2+}$ ions and of the silanol produced by the hydrolysis of alkoxysilane. Upon heating, condensation reaction of two adjacent silanol groups and release one water molecule occurred, thus forming siloxane bonds. In this peculiar case, conditions should be properly optimised to favour a very slow polymerisation process around the nanospheres, therefore minimising the inter-particles cross-linking. Among these conditions, the temperature plays a relevant important factor: mild temperature favours van der Waals force between silanol bridges, hence promoting a later condensation reaction to form covalent siloxane bonds (-Si-O-Si-). In general, this adaptation of the Stöber process [403] has been reported to be effective in coating different kinds of inorganic NP, some of them described in the following case studies, and of CdS. This is not strictly a functionalisation, but the approach was effective in providing the particles long term colloidal stability.

\subsection{Copper Sulphide}

Copper (II) sulphide (CuS) [10,12,32,404] has attracted considerable interest for its potential use as a material for transparent conductive films [12] able to transmit only the visible part of the solar spectrum, as a catalyst [405] and as a filler to enhance conductivity or wear resistance of polymeric materials. Doping with CuS was also reported to raise the critical temperature of some superconductors. Additionally, CuS is attracting a growing interest for application in photothermal therapy and in general in theranostics [10].

The crystalline hexagonal phase (covellite) of CuS, displaying an interesting and unusual structure envisioning the presence of both $\mathrm{Cu}^{\mathrm{I}}$ and $\mathrm{Cu}^{\mathrm{II}}$ and both trigonal and tetrahedral coordination of copper [406], is often described as a semiconductor and its reported band gap values, obtained from UV-Vis-NIR absorption spectra, range between $1.4 \mathrm{eV}$ and $2.2 \mathrm{eV}$. Modelling of the CuS electronic structure also suggests a metallic behaviour. Such different results about metallic and semiconductive behaviour of CuS can be explained by considering that, even if the bulk solid behaving like a metal, a band gap can still be originated due to size confinement effects in nanocrystalline samples.

Different routes for the synthesis of CuS nanoparticles were developed, including the use of nucleation from solution, hydrothermal conditions, microemulsions, use of chelating agents, sonochemical methods, as reported in some of the already mentioned reviews and relevant papers on the topic $[10,31,140,161,407-410]$.

As far as functionalisation is concerned, in the case of copper sulphide, very few examples could be retrieved in the literature in this regard.

In a contribution by Ang et al. [120], heterostructured CuS-ZnS nanocrystals (NCs) and Cu-doped ZnS (ZnS:Cu) NCs synthesized by two different protocols were investigated. These NCs were coated with a thin silica shell by using (3-mercaptopropyl)triethoxysilane in a reverse microemulsion to make them water soluble. Cytotoxicity experiments showed that these silica-coated NCs displayed low toxicity on both cancerous HeLa and noncancerous Chinese hamster ovary cells. The labelling of cancerous HeLa cells was also demonstrated.

In a paper by Kryukov et al., copper(II) sulphide stabilised in aqueous solutions by sodium polyphosphate [411] was reported, though also in this case no clear evidence of the interaction between the covellite nanoparticles and the stabiliser was provided.

Analogously to the previously discussed ZnS case study, chitosan functionalized CuS nanoparticles around $15 \mathrm{~nm}$ were prepared by employing the hydrothermal method. The modification of CuS nanoparticles with chitosan led to higher physiological stability and biocompatibility [412].

In a further example, manganese (II) chelate functionalized copper sulphide nanoparticles (CuS@MPG NPs) were successfully prepared using a facile hydrothermal method and employed 
for their excellent photothermal effect and photoaoustic activity [413]. In this case, no clear evidence regarding neither the actual chemical nature of the surface (CuS or either oxidized species) nor the chemical nature of the functionalisation was provided, and the authors only stated that "The powdery CuS@MPG NPs were quite stable and could be stored for several months without any obvious change" without reporting any experimental data in this regard, which makes the assessment difficult.

\subsection{Iron Sulphide}

Iron sulphides ( $\mathrm{FeS}, \mathrm{FeS}_{2}, \mathrm{Fe}_{2} \mathrm{~S}_{3}$ ) are fewer in number than the corresponding oxides and based on lower oxidation states, being also the pyrite mineral built of $\mathrm{Fe}^{\mathrm{II}}$ and $\mathrm{S}_{2}{ }^{2-}$ ions in a distorted rock-salt structure. Concerning iron sulphides, very few examples could be retrieved in the literature, dealing with their derivatisation. Among these ones, some [414-416] report on iron sulphide which was stabilised by using carboxymethyl cellulose as stabilising ligand. In one case [416], the nanoparticles were prepared using a low-cost, food-grade cellulose (sodium carboxymethyl cellulose, CMC) as the stabiliser. The hydrodynamic diameter of fresh FeS-CMC nanoparticles was measured to be about $40 \mathrm{~nm}$. In this case, the successful formation of CMC-FeS could be only indirectly assessed by verifying the very low polydispersity index, suggesting a quite monodisperse system. In a previous paper on the topic [414], evidence that attachment of CMC onto the surface of FeS particles induced strong electrostatic repulsion between the negatively charged particles was also provided based on zeta potential measurements [414]. Furthermore, when stored in sealed vials under anaerobic conditions at room temperature, the CMC-FeS NP did not display any visual sedimentation over a period of several weeks. However, the nanoparticles were quickly oxidised when coming in contact with air, turning the black suspension into a yellowish-orange coloured solution. In a further paper, adsorption of cetylpyridinium chloride (CPC), a cationic surfactant, on pyrite surface was investigated in its suspension, showing a CPC adsorption capacity dependence upon $\mathrm{pH}$ [268] (see Figure 10). Zeta potential of pyrite surface changed from positive to negative value by the addition of $\mathrm{NaCl}$. Though the absorption cannot be considered a stable functionalisation, this study provides basic understanding of the adsorption mechanism of cationic surfactant on pyrite surface at different $\mathrm{pH}$ conditions.

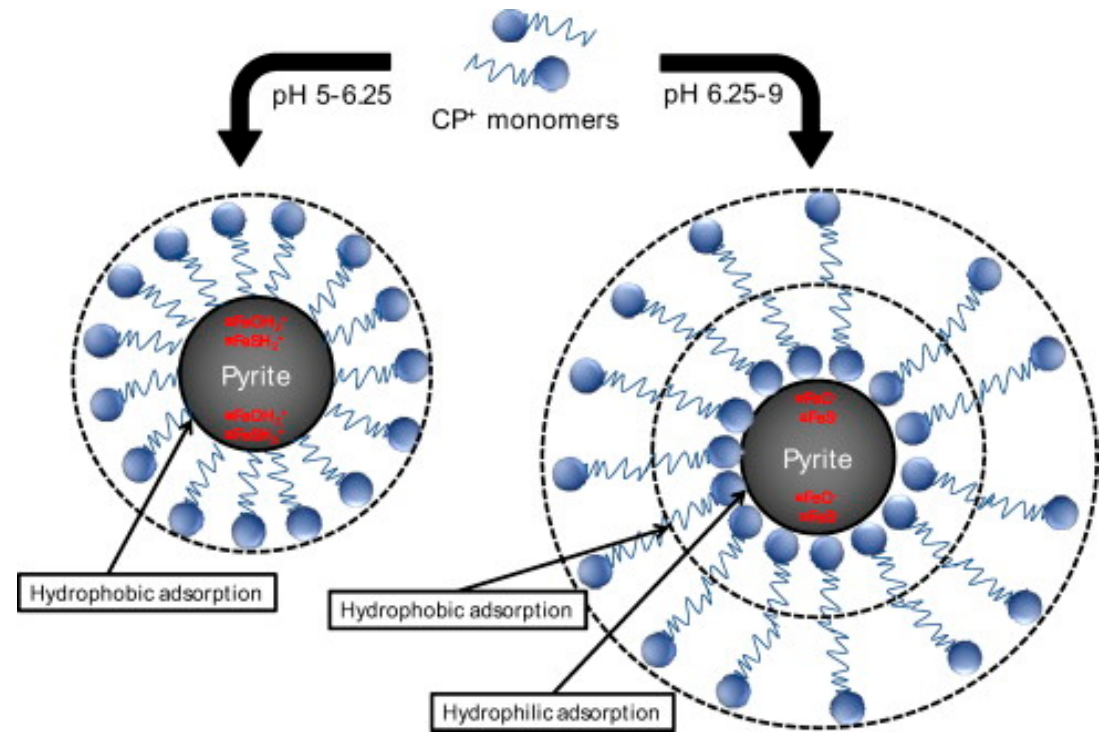

Figure 10. Schematic illustration for adsorption of cetylpyridinium chloride (CPC) on pyrite surface at different $\mathrm{pH}$ ranges. Taken from Ref. [268]. Copyright 2012 Elsevier. 


\subsection{Molybdenum Sulphide}

Molybdenum disulphide, $\mathrm{MoS}_{2}$, is a very interesting transition metal chalcogenide, and the most stable among Mo sulphides. It displays a peculiar structure, elucidated by Pauling in 1923 [417], consisting of layers of $\mathrm{MoS}_{2}$ in which Mo atoms are each coordinated to 6 sulphide atoms, forming not the usual octahedron, but rather a trigonal prism [58]. The layered structure favours the easy cleavage along the planes, thus explaining also the lubricants properties. Indeed, being well investigated as lubricant [418], $\mathrm{MoS}_{2}$ has recently attracted attention also as interesting material for the development of catalysts in many hydrogenation and in general catalytic reactions $[419,420]$. By activating the $\mathrm{MoS}_{2}$ basal plane, the hydrogen evolution reaction (HER) could be further enhanced. Theoretical and experimental results show that the S-vacancies are the catalytic sites in the basal plane, where gap states around the Fermi level allow hydrogen to bind directly to exposed Mo atoms. Molybdenum-sulphide-based catalysts has also found potential application in lithium-ion batteries (LIBs) and supercapacitors (SCs) applications [27].

Also in this case, few papers dealing with functionalisation of this sulphide could be retrieved, also because applications in bio-related disciplines have not yet been assessed. One of the most relevant paper on derivatisation is one reporting on the synthesis of edge-oriented $\mathrm{MoS}_{2}$ nanosheets by the evaporation of a single source precursor [40]. The surface chemistry of the $\mathrm{MoS}_{2}$ nanosheets has been studied in order to evaluate the chemical reactivity of the basal planes and edges. In this case, the functionalisation of the basal plane with 1-pyrene acetic acid allows the immobilization of DNA and immunoglobins on the $\mathrm{MoS}_{2}$ basal plane for biosensing purposes. In particular, the $\mathrm{MoS}_{2}$ film was treated with 1-pyrene acetic acid in order to introduce $\mathrm{COOH}$ groups on the basal planes of the $\mathrm{MoS}_{2}$ for tethering to $\mathrm{NH}_{2}$-terminal DNA and proteins. 1-Pyrene acetic acid has four six-membered rings which can adsorb via van der Waals bonding on graphitic-like planes. Evidence of the occurred anchoring was provided by FT-IR showing that following treatment with 1-pyrene acetic acid and washing with buffer solution. Distinct peaks at 1700 and $1650 \mathrm{~cm}^{-1}$ assignable to the $\mathrm{C}=\mathrm{O}$ and $\mathrm{C}-\mathrm{C}$ stretching could be evidenced. Afterwards, EDC was used to activate the $\mathrm{COOH}$ groups of the $\mathrm{MoS}_{2}$ samples to facilitate the formation of amide bonds with the $\mathrm{NH}_{2}$-DNA probe. The DNA-immobilized $\mathrm{MoS}_{2}$ was then used to assay for the labelled complementary DNA. By using the different emission filters, the $\mathrm{NH}_{2}$-DNA probes and labelled targets were imaged separately, showing effectiveness of the functionalisation procedure.

\section{Conclusions}

This review has collected the most relevant examples retrieved in the state of the art on nanostructured transition metal sulphide surface chemistry and on selected case studies dealing with their functionalisation. The main goal of this contribution was to provide an overview on the still inhomogeneous and sometimes contradictory state-of-the-art in this field as well as to try to unify the picture on the complex surface chemistry of this peculiar class of inorganic compounds. Endeavours towards a deeper understanding of the presence and nature of different species on the sulphide surface, their dependence on experimental factors ( $\mathrm{pH}$, temperature, potential, solvent etc.) and to the development of effective functionalisation strategies leading to stable and robust anchoring of the functionalising moieties, are challenging but worth to be pursued, since the establishment of effective derivatisation strategies would enable to further widen the functional applications of metal sulphides. This collection of relevant examples has also pointed out as, to address a systematic and reliable investigation of metal sulphides surface, the combination of different analytical approaches and theoretical tools is highly desired.

As outlined by Balantseva et al. [164], very few techniques are available to study the surface properties of sulphide colloids, so that often indirect methods and combination of different analytical tools are necessary. Among these, the use of in situ infrared spectroscopy has been proven, also in the case of oxides, to be a very powerful tool, especially when coupled to theoretical modelling allowing the calculation of energy, structure, and vibrational frequencies of simple molecules weakly interacting 
with the surface. Adsorption of small molecules, followed by DRIFT, has also demonstrated to be useful to unveil acid/base properties of surfaces [421-425].

As outlined in Section 2.3, a further valuable tool in the understanding of NC/ligands interactions is offered also by NMR spectroscopy. The possibilities offered by ${ }^{1} \mathrm{H}$ solution NMR for the study of colloidal nanocrystal ligands have been reviewed by Hens and Martins [253] and De Roo [251]. Using CdSe and PbSe nanocrystals with tightly bound oleate ligands as examples, solution NMR for ligand analysis was used. In particular, the authors explored the capabilities of diffusion ordered (DOSY) and nuclear Overhauser effect (NOESY) spectroscopy as NMR-related techniques which enable bound ligands to be distinguished from free ligands.

Additionally, as witnessed by the literature surveyed in this review, analytical methods to study colloids such as zeta-potential measurements, combined with potentiometric titration, adsorption and solution speciation modelling, could enable to unravel the effective nature of even complex surfaces (in terms of surface acidity, surface stoichiometry and surface proton binding site), whose chemistry has been shown to be affected, inter alia, by species concentration, $\mathrm{pH}$, temperature, surrounding environment.

In this regard, a still open challenging task for the chemist is to better understand the surface chemistry of metal sulphides, its dependence from experimental parameters, and to design new functionalisation strategies to effectively address their long-term stabilisation. In this endeavour, the preparative chemist need to be supported also by theoreticians who are able to reliably model the surface.

Author Contributions: S.G. conceived the topic and structure of the review; N.D. performed carefully literature survey and its organisation. A.V. wrote the part on surface chemistry of sulphides, S.G. wrote the rest of the paper. A.V. and N.D. critically revised the whole text and added some sections.

Conflicts of Interest: The authors declare no conflict of interest.

\section{References}

1. Biju, V.; Itoh, T.; Anas, A.; Sujith, A.; Ishikawa, M. Semiconductor quantum dots and metal nanoparticles: Syntheses, optical properties, and biological applications. Anal. Bioanal. Chem. 2008, 391, 2469-2495. [CrossRef] [PubMed]

2. Bilecka, I.; Niederberger, M. New developments in the nonaqueous and/or non-hydrolytic sol-gel synthesis of inorganic nanoparticles. Electrochim. Acta 2010, 55, 7717-7725. [CrossRef]

3. Bowles, K.C.; Bell, R.A.; Ernste, M.J.; Kramer, J.R.; Manolopoulos, H.; Ogden, N. Synthesis and characterization of metal sulfide clusters for toxicological studies. Environ. Toxicol. Chem. 2002, 21, 693-699. [CrossRef] [PubMed]

4. Bruehwiler, D.; Seifert, R.; Calzaferri, G. Quantum-Sized Silver Sulfide Clusters in Zeolite A. J. Phys. Chem. B 1999, 103, 6397-6399. [CrossRef]

5. Da Costa, J.P.; Girao, A.V.; Trindade, T.; Costa, M.C.; Duarte, A.; Rocha-Santos, T. Biological synthesis of nanosized sulfide semiconductors: Current status and future prospects. Appl. Microbiol. Biotechnol. 2016, 100, 8283-8302. [CrossRef] [PubMed]

6. Dahl, J.A.; Maddux, B.L.S.; Hutchison, J.E. Toward Greener Nanosynthesis. Chem. Rev. 2007, 107, $2228-2269$. [CrossRef] [PubMed]

7. Dunne, P.W.; Munn, A.S.; Starkey, C.L.; Huddle, T.A.; Lester, E.H. Continuous-flow hydrothermal synthesis for the production of inorganic nanomaterials. Philos. Trans. R. Soc. a-Math. Phys. Eng. Sci. 2015, 373, 20150015. [CrossRef] [PubMed]

8. Fang, X.; Zhai, T.; Gautam, U.K.; Li, L.; Wu, L.; Bando, Y.; Golberg, D. ZnS nanostructures: From synthesis to applications. Prog. Mater. Sci. 2011, 56, 175-287. [CrossRef]

9. Faramarzi, M.A.; Sadighi, A. Insights into biogenic and chemical production of inorganic nanomaterials and nanostructures. Adv. Colloid Interface Sci. 2013, 189, 1-20. [CrossRef] [PubMed]

10. Goel, S.; Chen, F.; Cai, W. Synthesis and biomedical applications of copper sulfide nanoparticles: From sensors to theranostics. Small 2014, 10, 631-645. [CrossRef] [PubMed] 
11. Gong, Y.Y.; Tang, J.C.; Zhao, D.Y. Application of iron sulfide particles for groundwater and soil remediation: A review. Water Res. 2016, 89, 309-320. [CrossRef] [PubMed]

12. Grijalva, H.; Inoue, M.; Boggavarapu, S.; Calvert, P. Amorphous and crystalline copper sulfides, CuS. J. Mater. Chem. 1996, 6, 1157-1160. [CrossRef]

13. Hendricks, M.P.; Campos, M.P.; Cleveland, G.T.; Jen-La Plante, I.; Owen, J.S. A tunable library of substituted thiourea precursors to metal sulfide nanocrystals. Science 2015, 348, 1226-1230. [CrossRef] [PubMed]

14. Hendricks, M.P.; Campos, M.P.; Cleveland, G.T.; Owen, J.S. Rapid access to substituted thioureas: A tunable library of precursors for metal sulfide nanocrystals. In Abstracts of Papers of the American Chemical Society (vol. 248). 1155 16TH ST, NW; American Chemical Society: Washington, DC, USA.

15. Hosseini, M.R.; Sarvi, M.N. Recent achievements in the microbial synthesis of semiconductor metal sulfide nanoparticles. Mat. Sci. Semicond. Proc. 2015, 40, 293-301. [CrossRef]

16. Kadlag, K.P.; Rao, M.J.; Nag, A. Ligand-Free, Colloidal, and Luminescent Metal Sulfide Nanocrystals. J. Phys. Chem. Lett. 2013, 4, 1676-1681. [CrossRef] [PubMed]

17. Kowshik, M.; Deshmukh, N.; Vogel, W.; Urban, J.; Kulkarni, S.K.; Paknikar, K.M. Microbial synthesis of semiconductor CdS nanoparticles, their characterization, and their use in the fabrication of an ideal diode. Biotechnol. Bioeng. 2002, 78, 583-588. [CrossRef] [PubMed]

18. Kristl, M.; Drofenik, M. Sonochemical synthesis of nanocrystalline mercury sulfide, selenide and telluride in aqueous solutions. Ultrason. Sonochem. 2008, 15, 695-699. [CrossRef] [PubMed]

19. Kristl, M.; Hojnik, N.; Gyergyek, S.; Drofenik, M. Sonochemical preparation of copper sulfides with different phases in aqueous solutions. Mater. Res. Bull. 2013, 48, 1184-1188. [CrossRef]

20. Kuzyniak, W.; Adegoke, O.; Sekhosana, K.; D’Souza, S.; Tshangana, S.C.; Hoffmann, B.; Ermilov, E.A.; Nyokong, T.; Hopfner, M. Synthesis and characterization of quantum dots designed for biomedical use. Int. J. Pharm. 2014, 466, 382-389. [CrossRef] [PubMed]

21. Lu, F.; Zhou, M.; Li, W.R.; Weng, Q.H.; Li, C.L.; Xue, Y.M.; Jiang, X.F.; Zeng, X.H.; Bando, Y.; Golberg, D. Engineering sulfur vacancies and impurities in $\mathrm{NiCO}_{2} \mathrm{~S}_{4}$ nanostructures toward optimal supercapacitive performance. Nano Energy 2016, 26, 313-323. [CrossRef]

22. Pileni, M.P. Colloidal assemblies used as templates to control the size, shape and self organization of nanoparticles. PCCP 1997, 101, 1578-1587. [CrossRef]

23. Pouretedal, H.R.; Norozi, A.; Keshavarz, M.H.; Semnani, A. Nanoparticles of zinc sulfide doped with manganese, nickel and copper as nanophotocatalyst in the degradation of organic dyes. J. Hazard. Mater. 2009, 162, 674-681. [CrossRef] [PubMed]

24. Qian, X.F.; Zhang, X.M.; Wang, C.; Wang, W.Z.; Xie, Y.; Qian, Y.T. Solvent-thermal preparation of nanocrystalline tin chalcogenide. J. Phys. Chem. Solids 1999, 60, 415-417. [CrossRef]

25. Ramasamy, K.; Malik, M.A.; Revaprasadu, N.; O’Brien, P. Routes to Nanostructured Inorganic Materials with Potential for Solar Energy Applications. Chem. Mater. 2013, 25, 3551-3569. [CrossRef]

26. Rickard, D.; Luther, G.W. Chemistry of iron sulfides. Chem. Rev. 2007, 107, 514-562. [CrossRef] [PubMed]

27. Rui, X.H.; Tan, H.T.; Yan, Q.Y. Nanostructured metal sulfides for energy storage. Nanoscale 2014, 6, 9889-9924. [CrossRef] [PubMed]

28. Sadovnikov, S.I.; Rempel, A.A. Synthesis of nanocrystalline silver sulfide. Inorg. Mater. 2015, 51, 759-766. [CrossRef]

29. Shiri, L.; Ghorbani-Choghamarani, A.; Kazemi, M. Sulfides Synthesis: Nanocatalysts in C-S Cross-Coupling Reactions. Aust. J. Chem. 2016, 69, 585-600. [CrossRef]

30. Teranishi, T.; Saruyama, M.; Kanehara, M. Seed-mediated synthesis of metal sulfide patchy nanoparticles. Nanoscale 2009, 1, 225-228. [CrossRef] [PubMed]

31. Tolia, J.; Chakraborty, M.; Murthy, Z.V.P. Synthesis and characterization of semiconductor metal sulfide nanocrystals using microemulsion technique. Cryst. Res. Technol. 2012, 47, 909-916. [CrossRef]

32. Van der Stam, W.; Berends, A.C.; Donega, C.D. Prospects of Colloidal Copper Chalcogenide Nanocrystals. Chemphyschem 2016, 17, 559-581. [CrossRef] [PubMed]

33. Wang, X.F.; Huang, H.T.; Liang, B.; Liu, Z.; Chen, D.; Shen, G.Z. ZnS Nanostructures: Synthesis, Properties, and Applications. Crit. Rev. Solid State Mater. Sci. 2013, 38, 57-90. [CrossRef]

34. Zhang, F.; Wong, S.S. Controlled synthesis of semiconducting metal sulfide nanowires. Chem. Mater. 2009, 21, 4541-4554. [CrossRef] 
35. Wang, D.-S.; Zheng, W.; Hao, C.-H.; Peng, Q.; Li, Y.-D. A Synthetic Method for Transition-Metal Chalcogenide Nanocrystals. Chem. Eur. J. 2009, 15, 1870-1875. [CrossRef] [PubMed]

36. Chemseddine, A. Metal-Oxide and-Sulfide Nanocrystals and Nanostructures; Wiley-VCH Verlag GmbH: Weinheim, Germany, 2000; pp. 315-352.

37. Hiratani, T.; Konishi, K. Functionalization of inorganic nanoclusters based on the molecular recognition events at the heterogeneous interface. J. Synth. Org. Chem. Jpn. 2008, 66, 239-248. [CrossRef]

38. Hertl, W. Surface chemical properties of zinc sulfide. Langmuir 1988, 4, 594-598. [CrossRef]

39. Lee, C.M.; Jang, D.; Cheong, S.J.; Kim, E.M.; Jeong, M.H.; Kim, S.H.; Kim, D.W.; Lim, S.T.; Sohn, M.H.; Jeong, H.J. Surface engineering of quantum dots for in vivo imaging. Nanotechnology 2010, 21, 285102. [CrossRef] [PubMed]

40. Zhang, H.; Loh, K.P.; Sow, C.H.; Gu, H.R.; Su, X.D.; Huang, C.; Chen, Z.K. Surface modification studies of edge-oriented molybdenum sulfide nanosheets. Langmuir 2004, 20, 6914-6920. [CrossRef] [PubMed]

41. Buonsanti, R.; Milliron, D.J. Chemistry of Doped Colloidal Nanocrystals. Chem. Mater. 2013, 25, $1305-1317$. [CrossRef]

42. Chen, J.-H.; Long, X.-H.; Zhao, C.-H.; Kang, D.; Guo, J. DFT calculation on relaxation and electronic structure of sulfide minerals surfaces in presence of $\mathrm{H}_{2} \mathrm{O}$ molecule. J. Cent. South Univ. 2014, 21, 3945-3954. [CrossRef]

43. Luther, G.W.; Rickard, D.T. Metal sulfide cluster complexes and their biogeochemical importance in the environment. J. Nanop. Res. 2005, 7, 389-407. [CrossRef]

44. Mal, J.; Nancharaiah, Y.V.; van Hullebusch, E.D.; Lens, P.N.L. Metal chalcogenide quantum dots: Biotechnological synthesis and applications. RSC Adv. 2016, 6, 41477-41495. [CrossRef]

45. Rosso, K.M. Reactivity of Sulfide Mineral Surfaces. Rev. Mineral. Geochem. 2006, 61, 557-607. [CrossRef]

46. Smet, P.F.; Moreels, I.; Hens, Z.; Poelman, D. Luminescence in sulfides: A rich history and a bright future. Materials 2010, 3, 2834-2883. [CrossRef]

47. Zhang, H.; Hyun, B.-R.; Wise, F.W.; Robinson, R.D. A Generic Method for Rational Scalable Synthesis of Monodisperse Metal Sulfide Nanocrystals. Nano Lett. 2012, 12, 5856-5860. [CrossRef] [PubMed]

48. Sorkin, V.; Pan, H.; Shi, H.; Quek, S.Y.; Zhang, Y.W. Nanoscale Transition Metal Dichalcogenides: Structures, Properties, and Applications. Crit. Rev. Solid State Mater. Sci. 2014, 39, 319-367. [CrossRef]

49. Acar, C.; Dincer, I.; Naterer, G.F. Review of photocatalytic water-splitting methods for sustainable hydrogen production. Int. J. Energy Res. 2016, 40, 1449-1473. [CrossRef]

50. Boles, M.A.; Ling, D.; Hyeon, T.; Talapin, D.V. The surface science of nanocrystals. Nat. Mater. 2016, 15, 141-153. [CrossRef] [PubMed]

51. Cuenya, B.R.; Behafarid, F. Nanocatalysis: Size- and shape-dependent chemisorption and catalytic reactivity. Surf. Sci. Rep. 2015, 70, 135-187. [CrossRef]

52. Frank, M.; Baumer, M. From atoms to crystallites: Adsorption on oxide-supported metal particles. Phys. Chem. Chem. Phys. 2000, 2, 3723-3737. [CrossRef]

53. Hebie, S.; Napporn, T.W.; Morais, C.; Kokoh, K.B. Size-Dependent Electrocatalytic Activity of Free Gold Nanoparticles for the Glucose Oxidation Reaction. Chemphyschem 2016, 17, 1454-1462. [CrossRef] [PubMed]

54. Liu, Y.L.; Gao, P.F.; Huang, C.Z.; Li, Y.F. Shape- and size-dependent catalysis activities of iron-terephthalic acid metal-organic frameworks. Sci. China-Chem. 2015, 58, 1553-1560. [CrossRef]

55. Mondal, J.; Trinh, Q.T.; Jana, A.; Ng, W.K.H.; Borah, P.; Hirao, H.; Zhao, Y.L. Size-Dependent Catalytic Activity of Palladium Nanoparticles Fabricated in Porous Organic Polymers for Alkene Hydrogenation at Room Temperature. ACS Appl. Mater. Interfaces 2016, 8, 15307-15319. [CrossRef] [PubMed]

56. Rozanska, X.; Fortrie, R.; Sauer, J. Size-Dependent Catalytic Activity of Supported Vanadium Oxide Species: Oxidative Dehydrogenation of Propane. J. Am. Chem. Soc. 2014, 136, 7751-7761. [CrossRef] [PubMed]

57. Alsfasser, R.; Janiak, C.; Klapötke, T.M.; Meyer, H.-J. Moderne Anorganische Chemie, 4th ed.; Walter de Gruyter: Berlin, Germany, 2012.

58. Greenwood, N.N.; Earnshaw, A. Chemistry of the Elements, 2nd ed.; Pergamon Press: Cambridge, UK, 1998.

59. Wells, A.F. Structural Inorganic Chemistry, 3rd ed.; Oxford University Press: Oxford, UK, 1962.

60. Müller, U. Anorganische Strukturchemie, 2nd ed.; Teubner Studienbuecher Chemie: Stuttgart, Germany, 1992.

61. Holleman, A.F.; Wiberg, E. Lehrbuch der Anorganischen Chemie, 101th ed.; W. de Gruyter \& Co: Berlin, Germany, 1985.

62. Pearson, G. Hard and Soft Acids and Bases. J. Am. Chem. Soc. 1963, 85, 3533-3539. [CrossRef] 
63. Cox, P.A. Transition Metal Oxides: Introduction to Their Electronic Structure and Properties; Oxford University Press: Oxford, UK, 1995; p. 272.

64. Shannon Radii-Atomistic Simulation Group. Available online: http://abulafia.mt.ic.ac.uk/shannon/ ptable.php. (accessed on 10 December 2016).

65. Shannon, R.D. Revised Effective Ionic Radii and Systematic Studies of Interatomie Distances in Halides and Chaleogenides. Acta Crystallogr. 1976, 32, 751-767. [CrossRef]

66. Miller, T.M.; Bederson, B. Atomic and molecular polarizabilities-A review of recent advances. Adv. At. Mol. Phys. 1978, 13, 1-55.

67. Lide, D.R. CRC Handbook of Chemistry and Physics, 53rd ed.; CRC Press: Boca Raton, FL, USA, 1995.

68. Evans, H.T.; Konnert, J.A. Crystal structure refinement of covellite. Am. Mineral. 1976, 61, 996-1000.

69. Prener, J.S. Nonstoichiometry in Chalcogenide Systems; American Chemical Society: Washington, DC, USA, 1963.

70. Pedoussaut, N.M.; Lind, C. Facile Synthesis of Troilite. Inorg. Chem. 2008, 47, 392-394. [CrossRef] [PubMed]

71. Geng, B.; Liu, X.; Ma, J.; Du, Q. A new nonhydrolytic single-precursor approach to surfactant-capped nanocrystals of transition metal sulfides. Mater. Sci. Eng. B 2007, 145, 17-22. [CrossRef]

72. Geng, B.; Liu, X.; Du, Q.; Ma, J.; Liu, X. Size-dependent blue luminescent CdS nanocrystals synthesized through a single-source molecular precursor route. Mater. Res. Bull. 2008, 43, 1093-1098. [CrossRef]

73. Ludi, B.; Olliges-Stadler, I.; Rossell, M.D.; Niederberger, M. Extension of the benzyl alcohol route to metal sulfides: "Nonhydrolytic" thio sol-gel synthesis of ZnS and SnS 2 . Chem. Commun. 2011, 47, 5280-5282. [CrossRef] [PubMed]

74. Qian, Y.; Su, Y.; Xie, Y.; Chen, Q.; Chen, Z. Hydrothermal preparation and characterization of nanocrystalline powder of sphalerite. Mater. Res. Bull. 1995, 30, 601-605.

75. Chen, Q.; Qian, Y.T.; Chen, Z.Y.; Shi, L.; Li, X.G.; Zhou, G.E.; Zhang, Y.H. Preparation of zinc sulfide thin films by the hydrothermal method. Thin Solid Films 1996, 272, 1-3. [CrossRef]

76. Chen, Q.; Li, X.; Qian, Y.; Zhu, J.; Zhou, G.; Zhang, W.; Zhang, Y. Photoluminescence in ultrafine zinc sulfide thin film. Appl. Phys. Lett. 1996, 68, 3582-3584. [CrossRef]

77. Li, Y.; Yi, D.; Yue, Z.; Qian, Y. Photophysical properties of ZnS quantum dots. J. Phys. Chem. Solids 1998, 60, 13-15. [CrossRef]

78. Zhang, H.; Wei, B.; Zhu, L.; Yu, J.; Sun, W.; Xu, L. Cation exchange synthesis of ZnS-Ag 2 S microspheric composites with enhanced photocatalytic activity. Appl. Surf. Sci. 2013, 270, 133-138. [CrossRef]

79. Yu, S.-H.; Yang, J.; Wu, Y.-S.; Han, Z.-H.; Lu, J.; Xie, Y.; Qian, Y.-T. A new low temperature one-step route to metal chalcogenide semiconductors: $\mathrm{PbE}, \mathrm{Bi}_{2} \mathrm{E}_{3}(\mathrm{E}=\mathrm{S}, \mathrm{Se}, \mathrm{Te})$. J. Mater. Chem. 1998, 8, 1949-1951. [CrossRef]

80. Chen, X.; Wang, Z.; Wang, X.; Zhang, R.; Liu, X.; Lin, W.; Qian, Y. Synthesis of novel copper sulfide hollow spheres generated from copper (II)-thiourea complex. J. Cryst. Growth 2004, 263, 570-574. [CrossRef]

81. Roy, P.; Srivastava, S.K. Hydrothermal Growth of CuS Nanowires from Cu-Dithiooxamide, a Novel Single-Source Precursor. Cryst. Growth Des. 2006, 6, 1921-1926. [CrossRef]

82. Liu, Z.; Peng, S.; Xie, Q.; Hu, Z.; Yang, Y.; Zhang, S.; Qian, Y. Large-scale synthesis of ultralong $\mathrm{Bi}_{2} \mathrm{~S}_{3}$ nanoribbons via a solvothermal process. Adv. Mater. 2003, 15, 936-940. [CrossRef]

83. Qian, Y.; Yu, D.; Liu, Z. Solvothermal synthesis route to one-dimensional nanostructures. Trans. Mater. Res. Soc. Jpn. 2004, 29, 2233-2238.

84. Qian, Y.T. Solvothermal synthesis of nanocrystalline III-V semiconductors. Adv. Mater. 1999, 11, 1101-1102. [CrossRef]

85. Li, Y.; Liao, H.; Ding, Y.; Fan, Y.; Zhang, Y.; Qian, Y. Solvothermal Elemental Direct Reaction to CdE (E = S, Se, Te) Semiconductor Nanorod. Inorg. Chem. 1999, 38, 1382-1387. [CrossRef]

86. Yang, J.; Zeng, J.-H.; Yu, S.-H.; Yang, L.; Zhou, G.-E.; Qian, Y.-T. Formation Process of CdS Nanorods via Solvothermal Route. Chem. Mater. 2000, 12, 3259-3263. [CrossRef]

87. Amiri, O.; Salavati-Niasari, M.; Sabet, M.; Ghanbari, D. Sonochemical method for preparation of copper indium sulfide nanoparticles and their application for solar cell. Comb. Chem. High Throughput Screen. 2014, 17, 183-189. [CrossRef] [PubMed]

88. Bang, J.H.; Suslick, K.S. Applications of Ultrasound to the Synthesis of Nanostructured Materials. Adv. Mater. 2010, 22, 1039-1059. [CrossRef] [PubMed]

89. Baranchikov, A.Y.; Ivanov, V.K.; Tretyakov, Y.D. Sonochemical synthesis of inorganic materials. Russ. Chem. Rev. 2007, 76, 133-151. [CrossRef] 
90. Behboudnia, M.; Khanbabaee, B. Conformational study of CdS nanoparticles prepared by ultrasonic waves. Colloids Surf. A Physicochem. Eng. Asp. 2006, 290, 229-232. [CrossRef]

91. Wang, S.F.; Gu, F.; Lü, M.K.; Zhou, G.J.; Zhang, A.Y. Sonochemical synthesis of PbS nanocubes, nanorods and nanotubes. J. Cryst. Growth 2006, 289, 621-625. [CrossRef]

92. García-Gómez, N.A.; de la Parra-Arcieniega, S.M.; Garza-Tovar, L.L.; Torres-González, L.C.; Sánchez, E.M. Ionic liquid-assisted sonochemical synthesis of SnS nanostructures. J. Alloy. Compd. 2014, 588, 638-643. [CrossRef]

93. Gedanken, A. Using sonochemistry for the fabrication of nanomaterials. Ultrason. Sonochem. 2004, 11, 47-55. [CrossRef] [PubMed]

94. Hao, L.-X.; Chen, G.; Yu, Y.-G.; Zhou, Y.-S.; Han, Z.-H.; Liu, Y. Sonochemistry synthesis of $\mathrm{Bi}_{2} \mathrm{~S}_{3} / \mathrm{CdS}$ heterostructure with enhanced performance for photocatalytic hydrogen evolution. Int. J. Hydrog. Energy 2014, 39, 14479-14486. [CrossRef]

95. Hosseini, Z.; Azizian-Kalandaragh, Y.; Khodayari, A.; Nedaee-Shakarab, B. Sonochemically prepared PbS nanostructures and investigation of their optical and structural properties. Optoelectron. Adv. Mater. 2014, 8, 201-203.

96. Kis-Csitári, J.; Kónya, Z.; Kiricsi, I. Sonochemical Synthesis of Inorganic Nanoparticles. In Functionalized Nanoscale Materials, Devices and Systems. NATO Science for Peace and Security Series B: Physics and Biophysics; Vaseashta, A., Mihailescu, I.N., Eds.; Springer: Dordrecht, The Netherlands, 2008; pp. 369-372.

97. Kumar, R.V.; Palchik, O.; Koltypin, Y.; Diamant, Y.; Gedanken, A. Sonochemical synthesis and characterization of $\mathrm{Ag}_{2} \mathrm{~S} / \mathrm{PVA}$ and CuS/PVA nanocomposite. Ultrason. Sonochem. 2002, 9, 65-70. [CrossRef]

98. Lee, G.-J.; Anandan, S.; Masten, S.J.; Wu, J.J. Sonochemical Synthesis of Hollow Copper Doped Zinc Sulfide Nanostructures: Optical and Catalytic Properties for Visible Light Assisted Photosplitting of Water. Ind. Eng. Chem. Res. 2014, 53, 8766-8772. [CrossRef]

99. Lopes, P.A.L.; Santos, M.B.; Mascarenhas, A.J.S.; Silva, L.A. Synthesis of CdS nano-spheres by a simple and fast sonochemical method at room temperature. Mater. Lett. 2014, 136, 111-113. [CrossRef]

100. Murcia, M.J.; Shaw, D.L.; Woodruff, H.; Naumann, C.A.; Young, B.A.; Long, E.C. Facile Sonochemical Synthesis of Highly Luminescent ZnS-Shelled CdSe Quantum Dots. Chem. Mater. 2006, 18, 2219-2225. [CrossRef]

101. Nowak, M.; Kauch, B.; Szperlich, P.; Stróz, D.; Szala, J.; Rzychoń, T.; Bober, Ł.; Toroń, B.; Nowrot, A. Sonochemical preparation of $\operatorname{SbS}_{(1-\mathrm{x})} \mathrm{Se}_{(\mathrm{x})} \mathrm{I}$ nanowires. Ultrason. Sonochem. 2010, 17, 487-493. [CrossRef] [PubMed]

102. Park, J.; Song, M.; Jung, W.M.; Lee, W.Y.; Kim, H.; Kim, Y.; Hwang, C.; Shim, I.-W. Syntheses of $\mathrm{Cu}_{2} \mathrm{SnS}_{3}$ and $\mathrm{Cu}_{2} \mathrm{ZnSnS}_{4}$ nanoparticles with tunable $\mathrm{Zn} / \mathrm{Sn}$ ratios under multibubble sonoluminescence conditions. Dalton Trans. 2013, 42, 10545-10550. [CrossRef] [PubMed]

103. Salinas-Estevané, P.; Sánchez, E.M. Preparation of $\mathrm{Sb}_{2} \mathrm{~S}_{3}$ Nanostructures by the Ionic Liquid-Assisted Sonochemical Method. Cryst. Growth Des. 2010, 10, 3917-3924. [CrossRef]

104. Wang, G.Z.; Geng, B.Y.; Huang, X.M.; Wang, Y.W.; Li, G.H.; Zhang, L.D. A convenient ultrasonic irradiation technique for in situ synthesis of zinc sulfide nanocrystallites at room temperature. Appl. Phys. A 2003, 77, 933-936. [CrossRef]

105. Wang, H.; Zhang, J.-R.; Zhao, X.-N.; Xu, S.; Zhu, J.-J. Preparation of copper monosulfide and nickel monosulfide nanoparticles by sonochemical method. Mater. Lett. 2002, 55, 253-258. [CrossRef]

106. Wu, G.S.; Yuan, X.Y.; Xie, T.; Xu, G.C.; Zhang, L.D.; Zhuang, Y.L. A simple synthesis route to CdS nanomaterials with different morphologies by sonochemical reduction. Mater. Lett. 2004, 58, 794-797. [CrossRef]

107. Yadav, R.S.; Mishra, P.; Mishra, R.; Kumar, M.; Pandey, A.C. Growth mechanism and optical property of CdS nanoparticles synthesized using amino-acid histidine as chelating agent under sonochemical process. Ultrason. Sonochem. 2010, 17, 116-122. [CrossRef] [PubMed]

108. Zhou, S.-M.; Zhang, X.-H.; Meng, X.-M.; Fan, X.; Lee, S.-T.; Wu, S.-K. Sonochemical synthesis of mass single-crystal PbS nanobelts. J. Solid State Chem. 2005, 178, 399-403. [CrossRef]

109. Zhu, J.; Liu, S.; Palchik, O.; Koltypin, Y.; Gedanken, A. A Novel Sonochemical Method for the Preparation of Nanophasic Sulfides: Synthesis of HgS and PbS Nanoparticles. J. Solid State Chem. 2000, 153, 342-348. [CrossRef]

110. Zhu, Y.-P.; Li, J.; Ma, T.-Y.; Liu, Y.-P.; Du, G.; Yuan, Z.-Y. Sonochemistry-assisted synthesis and optical properties of mesoporous ZnS nanomaterials. J. Mater. Chem. A 2014, 2, 1093. [CrossRef] 
111. Kharazmi, A.; Saion, E.; Faraji, N.; Hussin, R.M.; Yunus, W.M.M. Structural, optical and thermal properties of PVA/CdS nanocomposites synthesized by radiolytic method. Radiat. Phys. Chem. 2014, 97, 212-216. [CrossRef]

112. Mostafavi, M.; Liu, Y.; Pernot, P.; Belloni, J. Dose rate effect on size of CdS clusters induced by irradiation. Radiat. Phys. Chem. 2000, 59, 49-59. [CrossRef]

113. Souici, A.H.; Keghouche, N.; Delaire, J.A.; Remita, H.; Mostafavi, M. Radiolytic synthesis and optical properties of ultra-small stabilized ZnS nanoparticles. Chem. Phys. Lett. 2006, 422, 25-29. [CrossRef]

114. Evans, J.E.; Jungjohann, K.L.; Browning, N.D.; Arslan, I. Controlled growth of nanoparticles from solution with in situ liquid transmission electron microscopy. Nano Lett. 2011, 11, 2809-2813. [CrossRef] [PubMed]

115. Hayes, D.; Micic, O.I.; Nenadovic, M.T.; Swayambunathan, V.; Meisel, D. Radiolytic production and properties of ultrasmall cadmium sulfide particles. J. Phys. Chem. 1989, 93, 4603-4608. [CrossRef]

116. Swayambunathan, V.; Hayes, D.; Schmidt, K.H.; Liao, Y.X.; Meisel, D. Thiol surface complexation on growing cadmium sulfide clusters. J. Am. Chem. Soc. 1990, 112, 3831-3837. [CrossRef]

117. Ni, Y.; Ge, X.; Liu, H.; Xu, X.; Zhang, Z. $\gamma$-Irradiation preparation of CdS nano-particles and their formation mechanism in non-water system. Radiat. Phys. Chem. 2001, 61, 61-64. [CrossRef]

118. Ullrich, B.; Ezumi, H.; Keitoku, S.; Kobayashi, T. Luminescence properties of p-type thin CdS films prepared by laser ablation. Mater. Sci. Eng. B Solid State Mater. Adv. Technol. 1995, 35, 117-119. [CrossRef]

119. Zhang, D.S.; Goekce, B.; Barcikowski, S. Laser Synthesis and Processing of Colloids: Fundamentals and Applications. Chem. Rev. 2017, 117, 3990-4103. [CrossRef] [PubMed]

120. Ang, H.X.; Bosman, M.; Thamankar, R.; Zulkifli, M.F.B.; Yen, S.K.; Hariharan, A.; Sudhaharan, T.; Selvan, S.T. Highly Luminescent Heterostructured Copper-Doped Zinc Sulfide Nanocrystals for Application in Cancer Cell Labeling. Chemphyschem 2016, 17, 2489-2495. [CrossRef] [PubMed]

121. Boutonnet, M.; Kizling, J.; Stenius, P.; Maire, G. The preparation of monodisperse colloidal metal particles from microemulsions. Colloids Surf. 1982, 5, 209-225. [CrossRef]

122. Chander, H. Development of nanophosphors-A review. Mater. Sci. Eng. R Rep. 2005, 49, 113-155. [CrossRef]

123. Cushing, B.L.; Kolesnichenko, V.L.; O'Connor, C.J. Recent Advances in the Liquid-Phase Syntheses of Inorganic Nanoparticles. Chem. Rev. 2004, 104, 3893-3946. [CrossRef] [PubMed]

124. Gao, L.; Wang, E.; Lian, S.; Kang, Z.; Lan, Y.; Wu, D. Microemulsion-directed synthesis of different CuS nanocrystals. Solid State Commun. 2004, 130, 309-312. [CrossRef]

125. Selvan, S.T.; Tan, T.T.Y.; Yi, D.K.; Jana, N.R. Functional and multifunctional nanoparticles for bioimaging and biosensing. Langmuir ACS J. Surf. Colloids 2010, 26, 11631-11641. [CrossRef] [PubMed]

126. Xu, S.J.; Chua, S.J.; Liu, B.; Gan, L.M.; Chew, C.H.; Xu, G.Q. Luminescence characteristics of impurities-activated $\mathrm{ZnS}$ nanocrystals prepared in microemulsion with hydrothermal treatment. Appl. Phys. Lett. 1998, 73, 478-480. [CrossRef]

127. Zhang, P.; Gao, L. Copper sulfide flakes and nanodisks. J. Mater. Chem. 2003, 13, 2007-2010. [CrossRef]

128. Agostiano, A.; Catalano, M.; Curri, M.L.; Della Monica, M.; Manna, L.; Vasanelli, L. Synthesis and structural characterisation of CdS nanoparticles prepared in a four-components "water-in-oil" microemulsion. Micron 2000, 31, 253-258. [CrossRef]

129. Curri, M.L.; Agostiano, A.; Manna, L.; Della Monica, M.; Catalano, M.; Chiavarone, L.; Spagnolo, V.; Lugara, M. Synthesis and characterization of CdS nanoclusters in a quarternary microemulsion: The role of the cosurfactant. J. Phys. Chem. B 2000, 104, 8391-8397. [CrossRef]

130. Fini, P.; Curri, M.L.; Castagnolo, M.; Ciampi, F.; Agostiano, A. Calorimetric study of US nanoparticle formation in w/o microemulsions. Mater. Sci. Eng. C Biomim. Supramol. Syst. 2003, 23, 1077-1081. [CrossRef]

131. Bechthold, N.; Tiarks, F.; Willert, M.; Landfester, K.; Antonietti, M. Miniemulsion polymerization: Applications and new materials. Macromol. Symp. 2000, 151, 549-555. [CrossRef]

132. Dolcet, P.; Maurizio, C.; Casarin, M.; Pandolfo, L.; Gialanella, S.; Badocco, D.; Pastore, P.; Speghini, A.; Gross, S. An Effective Two-Emulsion Approach to the Synthesis of Doped ZnS Crystalline Nanostructures. Eur. J. Inorg. Chem. 2015, 2015, 706-714. [CrossRef]

133. Landfester, K. Synthesis of colloidal particles in miniemulsions. Annu. Rev. Mater. Res. 2006, 36, $231-279$. [CrossRef]

134. Landfester, K. Miniemulsions for nanoparticle synthesis. Top. Curr. Chem. 2003, 227, 75-123.

135. Landfester, K. Recent developments in miniemulsions-Formation and stability mechanisms. Macromol. Symp. 2000, 150, 171-178. [CrossRef] 
136. Landfester, K. The Generation of Nanoparticles in Miniemulsions. Adv. Mater. 2001, 13, 765-768. [CrossRef]

137. Landfester, K. Miniemulsions for Nanoparticle Synthesis. In Colloid Chemistry II; Antonietti, M., Ed.; Springer: Berlin/Heidelberg, Germany, 2003; Volume 227, pp. 75-123.

138. Muñoz-Espí, R.; Weiss, C.K.; Landfester, K. Inorganic nanoparticles prepared in miniemulsion. Curr. Opin. Colloid Interface Sci. 2012, 17, 212-224. [CrossRef]

139. Carbone, L.; Cozzoli, P.D. Colloidal heterostructured nanocrystals: Synthesis and growth mechanisms. Nano Today 2010, 5, 449-493. [CrossRef]

140. Armelao, L.; Camozzo, D.; Gross, S.; Tondello, E. Synthesis of copper sulfide nanoparticles in carboxylic acids as solvent. J. Nanosci. Nanotechnol. 2006, 6, 401-408. [CrossRef] [PubMed]

141. Grzelczak, M.; Liz-Marzan, L.M. The relevance of light in the formation of colloidal metal nanoparticles. Chem. Soc. Rev. 2014, 43, 2089-2097. [CrossRef] [PubMed]

142. Kwon, S.G.; Hyeon, T. Colloidal Chemical Synthesis and Formation Kinetics of Uniformly Sized Nanocrystals of Metals, Oxides, and Chalcogenides. Acc. Chem. Res. 2008, 41, 1696-1709. [CrossRef] [PubMed]

143. Leon-Velazquez, M.S.; Irizarry, R.; Castro-Rosario, M.E. Nucleation and Growth of Silver Sulfide Nanoparticles. J. Phys. Chem. C 2010, 114, 5839-5849. [CrossRef]

144. Lewis, A.E. Review of metal sulphide precipitation. Hydrometallurgy 2010, 104, 222-234. [CrossRef]

145. Mudring, A.-V.; Alammar, T.; Baecker, T.; Richter, K. Nanoparticle synthesis in ionic liquids. ACS Symp. Ser. 2009, 1030, 177-188.

146. Muñoz-Espì, R.; Mastai, Y.; Gross, S.; Landfester, K. Colloidal systems for crystallization processes from liquid phase. CrystEngComm 2013, 15, 2175-2191. [CrossRef]

147. Najmaei, S.; Lou, J. Synthesis, Characterization and Engineering of Two-Dimensional Transition Metal Dichalcogenides. In Proceedings of the 2014 IEEE 14th International Conference on Nanotechnology (IEEE-Nano), Toronto, ON, Canada, 18-21 August 2014; pp. 616-619.

148. Palberg, T. Crystallization kinetics of colloidal model suspensions: Recent achievements and new perspectives. J. Phys. Condens. Matter 2014, 26, 333101. [CrossRef] [PubMed]

149. Rempel, J.Y.; Bawendi, M.G.; Jensen, K.F. Insights into the Kinetics of Semiconductor Nanocrystal Nucleation and Growth. J. Am. Chem. Soc. 2009, 131, 4479-4489. [CrossRef] [PubMed]

150. Tao, A.R.; Habas, S.; Yang, P.D. Shape control of colloidal metal nanocrystals. Small 2008, 4, 310-325. [CrossRef]

151. Thanh, N.T.K.; Maclean, N.; Mahiddine, S. Mechanisms of Nucleation and Growth of Nanoparticles in Solution. Chem. Rev. 2014, 114, 7610-7630. [CrossRef] [PubMed]

152. Warad, H.C.; Ghosh, C.K.; Hemtanon, B.; Thanachayanont, C.; Dutta, J. Luminescent nanoparticles of Mn doped ZnS passivated with sodium hexametaphosphate. Sci. Technol. Adv. Mater. 2005, 6, 296. [CrossRef]

153. Burda, C.; Chen, X.; Narayanan, R.; El-Sayed, M.A. Chemistry and Properties of Nanocrystals of Different Shapes. Chem. Rev. 2005, 105, 1025-1102. [CrossRef] [PubMed]

154. Dharsana, U.S.; Varsha, M.; Behlol, A.A.K.; Veerappan, A.; Thiagarajan, R. Sulfidation modulates the toxicity of biogenic copper nanoparticles. RSC Adv. 2015, 5, 30248-30259. [CrossRef]

155. Gonzalez-Estrella, J.; Puyol, D.; Sierra-Alvarez, R.; Field, J.A. Role of biogenic sulfide in attenuating zinc oxide and copper nanoparticle toxicity to acetoclastic methanogenesis. J. Hazard. Mater. 2015, 283, 755-763. [CrossRef] [PubMed]

156. Lee, J.H.; Kennedy, D.W.; Dohnalkova, A.; Moore, D.A.; Nachimuthu, P.; Reed, S.B.; Fredrickson, J.K. Manganese sulfide formation via concomitant microbial manganese oxide and thiosulfate reduction. Environ. Microbiol. 2011, 13, 3275-3288. [CrossRef] [PubMed]

157. Rubilar, O.; Rai, M.; Tortella, G.; Diez, M.C.; Seabra, A.B.; Duran, N. Biogenic nanoparticles: Copper, copper oxides, copper sulphides, complex copper nanostructures and their applications. Biotechnol. Lett. 2013, 35, 1365-1375. [CrossRef] [PubMed]

158. Suresh, A.K.; Doktycz, M.J.; Wang, W.; Moon, J.W.; Gu, B.H.; Meyer, H.M.; Hensley, D.K.; Allison, D.P.; Phelps, T.J.; Pelletier, D.A. Monodispersed biocompatible silver sulfide nanoparticles: Facile extracellular biosynthesis using the gamma-proteobacterium, Shewanella oneidensis. Acta Biomater. 2011, 7, 4253-4258. [CrossRef] [PubMed]

159. Jacob, J.M.; Lens, P.N.L.; Balakrishnan, R.M. Microbial synthesis of chalcogenide semiconductor nanoparticles: A review. Microb. Biotechnol. 2016, 9, 11-21. [CrossRef] [PubMed]

160. Mitzi, D.B. Solution Processing of Inorganic Materials; John Wiley \& Sons: New York, NY, USA, 2009. 
161. Diodati, S.; Dolcet, P.; Casarin, M.; Gross, S. Pursuing the Crystallization of Mono- and Polymetallic Nanosized Crystalline Inorganic Compounds by Low-Temperature Wet-Chemistry and Colloidal Routes. Chem. Rev. 2015, 115, 11449-11502. [CrossRef] [PubMed]

162. Mitzi, D.B. Solution-processed inorganic semiconductors. J. Mater. Chem. 2004, 14, 2355-2365. [CrossRef]

163. Sharma, V.K.; Filip, J.; Zboril, R.; Varma, R.S. Natural inorganic nanoparticles—Formation, fate, and toxicity in the environment. Chem. Soc. Rev. 2015, 44, 8410-8423. [CrossRef] [PubMed]

164. Balantseva, E.; Berlier, G.; Camino, B.; Lessio, M.; Ferrari, A.M. Surface Properties of ZnS Nanoparticles: A Combined DFT and Experimental Study. J. Phys. Chem. C 2014, 118, 23853-23862. [CrossRef]

165. Busca, G. The surface acidity of solid oxides and its characterization by IR spectroscopic methods. An attempt at systematization. Phys. Chem. Chem. Phys. 1999, 1, 723-736. [CrossRef]

166. Busca, G.; Lorenzelli, V. Infrared spectroscopic identification of species arising from reactive adsorption of carbon oxides on metal oxide surfaces. Mater. Chem. 1982, 7, 89-126. [CrossRef]

167. Ramis, G.; Busca, G.; Lorenzelli, V. Low-temperature $\mathrm{CO}_{2}$ adsorption on metal oxides: Spectroscopic characterization of some weakly adsorbed species. Mater. Chem. Phys. 1991, 29, 425-435. [CrossRef]

168. Dinter, N.; Rusanen, M.; Raybaud, P.; Kasztelan, S.; da Silva, P.; Toulhoat, H. Temperature-programed reduction of unpromoted $\mathrm{MoS}_{2}$-based hydrodesulfurization catalysts: Experiments and kinetic modeling from first principles. J. Catal. 2009, 267, 67-77. [CrossRef]

169. Vaughan, D.J.; Becker, U.; Wright, K. Sulphide mineral surfaces: Theory and experiment. Int. J. Miner. Process. 1997, 51, 1-14. [CrossRef]

170. Emin, S.; Lisjak, D.; Pitcher, M.; Valant, M. Structural and morphological transformations of textural porous zinc sulfide microspheres. Microporous Mesoporous Mater. 2013, 165, 185-192. [CrossRef]

171. Hamad, S.; Cristol, S.; Catlow, C.R.A. Surface structures and crystal morphology of ZnS: Computational study. J. Phys. Chem. B 2002, 106, 11002-11008. [CrossRef]

172. Balantseva, E.; Camino, B.; Ferrari, A.M.; Berlier, G. Effect of Post-Synthesis Treatments on the Properties of ZnS Nanoparticles: An Experimental and Computational Study. Oil Gas Sci. Technol. Revue d'IFP Energies Nouvelles 2015, 70, 817-829. [CrossRef]

173. Tasker, P.W. The stability of ionic crystal surfaces. J. Phys. C 1979, 12, 4977-4984. [CrossRef]

174. Wells, S.; Alfe, D.; Blanchard, L.; Brodholt, J.; Calleja, M.; Catloe, R.; Price, D.; Tyler, R.; Wright, K. Ab-initio simulations of magnetic iron sulphides. Mol. Simul. 2005, 31, 379-384. [CrossRef]

175. Spirko, J.A.; Neiman, M.L.; Oelker, A.M.; Klier, K. Electronic structure and reactivity of defect MoS $_{2}$ I. Relative stabilities of clusters and edges, and electronic surface states. Surf. Sci. 2003, 542, 192-204. [CrossRef]

176. Hung, A.; Muscat, J.; Yarovsky, I.; Russo, S.P. Density-functional theory studies of pyrite FeS 2 (111) and (210) surfaces. Surf. Sci. 2002, 520, 111-119. [CrossRef]

177. Wen, X.D.; Ren, J.; Li, Y.W.; Wang, J.G.; Jiao, H.J. NO adsorption on triangular $\mathrm{Mo}_{28} \mathrm{~S}_{60}$ cluster. Chem. Phys. Lett. 2007, 436, 209-212. [CrossRef]

178. Wen, X.D.; Zeng, T.; Teng, B.T.; Zhang, F.Q.; Li, Y.W.; Wang, H.G.; Jiao, H.J. Hydrogen adsorption on a Mo(27)S(54)cluster: A density functional theory study. J. Mol. Catal. A Chem. 2006, 249, 191-200. [CrossRef]

179. Temel, B.; Tuxen, A.K.; Kibsgaard, J.; Topsoe, N.Y.; Hinnemann, B.; Knudsen, K.G.; Topsoe, H.; Lauritsen, J.V.; Besenbacher, F. Atomic-scale insight into the origin of pyridine inhibition of $\mathrm{MoS}_{2}$-based hydrotreating catalysts. J. Catal. 2010, 271, 280-289. [CrossRef]

180. Tuxen, A.; Gobel, H.; Hinnemann, B.; Li, Z.S.; Knudsen, K.G.; Topsoe, H.; Lauritsen, J.V.; Besenbacher, F. An atomic-scale investigation of carbon in $\mathrm{MoS}_{2}$ hydrotreating catalysts sulfided by organosulfur compounds. J. Catal. 2011, 281, 345-351. [CrossRef]

181. Topsoe, N.Y.; Tuxen, A.; Hinnemann, B.; Lauritsen, J.V.; Knudsen, K.G.; Besenbacher, F.; Topsoe, H. Spectroscopy, microscopy and theoretical study of $\mathrm{NO}$ adsorption on $\mathrm{MoS}_{2}$ and Co-Mo-S hydrotreating catalysts. J. Catal. 2011, 279, 337-351. [CrossRef]

182. Joshi, H.M.; Lin, Y.P.; Aslam, M.; Prasad, P.V.; Schultz-Sikma, E.A.; Edelman, R.; Meade, T.; Dravid, V.P. Effects of Shape and Size of Cobalt Ferrite Nanostructures on Their MRI Contrast and Thermal Activation. J. Phys. Chem. C 2009, 113, 17761-17767. [CrossRef] [PubMed]

183. Moses, P.G.; Grabow, L.C.; Fernandez, E.M.; Hinnemann, B.; Topsoe, H.; Knudsen, K.G.; Norskov, J.K. Trends in Hydrodesulfurization Catalysis Based on Realistic Surface Models. Catal. Lett. 2014, 144, 1425-1432. [CrossRef] 
184. Li, H.; Tsai, C.; Koh, A.L.; Cai, L.L.; Contryman, A.W.; Fragapane, A.H.; Zhao, J.H.; Han, H.S.; Manoharan, H.C.; Abild-Pedersen, F.; et al. Activating and optimizing $\mathrm{MoS}_{2}$ basal planes for hydrogen evolution through the formation of strained sulphur vacancies. Nat. Mater. 2016, 15, 48. [CrossRef] [PubMed]

185. Tsyganenko, A.A.; Can, F.; Travert, A.; Mauge, F. FTIR study of unsupported molybdenum sulfide-In situ synthesis and surface properties characterization. Appl. Catal. A Gen. 2004, 268, 189-197. [CrossRef]

186. Mauge, F.; Lamotte, J.; Nesterenko, N.S.; Manoilova, O.; Tsyganenko, A.A. FT-IR study of surface properties of unsupported $\mathrm{MoS}_{2}$. Catal. Today 2001, 70, 271-284. [CrossRef]

187. Siriwardane, R.V.; Woodruff, S. In Situ Fourier Transform Infrared Characterization of Sulfur Species Resulting from the Reaction of Water Vapor and Oxygen with Zinc Sulfide. Ind. Eng. Chem. Res. 1997, 36, 5277-5281. [CrossRef]

188. Kendelewicz, T.; Doyle, C.S.; Bostick, B.C.; Brown, G.E. Initial oxidation of fractured surfaces of FeS $2(100)$ by molecular oxygen, water vapor, and air. Surf. Sci. 2004, 558, 80-88. [CrossRef]

189. Guevremont, J.M.; Bebie, J.; Elsetinow, A.R.; Strongin, D.R.; Schoonen, M.A.A. Reactivity of the (100) plane of pyrite in oxidizing gaseous and aqueous environments: Effects of surface imperfections. Environ. Sci. Technol. 1998, 32, 3743-3748. [CrossRef]

190. Guevremont, J.M.; Elsetinow, A.R.; Strongin, D.R.; Bebie, J.; Schoonen, M.A.A. Structure sensitivity of pyrite oxidation: Comparison of the (100) and (111) planes. Am. Mineral. 1998, 83, 1353-1356. [CrossRef]

191. Guevremont, J.M.; Strongin, D.R.; Schoonen, M.A.A. Thermal chemistry of $\mathrm{H}_{2} \mathrm{~S}$ and $\mathrm{H}_{2} \mathrm{O}$ on the (100) plane of pyrite: Unique reactivity of defect sites. Am. Mineral. 1998, 83, 1246-1255. [CrossRef]

192. Blanchard, M.; Wright, K.; Gale, J.D.; Catlow, C.R.A. Adsorption of As(OH)(3) on the (001) surface of FeS 2 pyrite: A quantum-mechanical DFT study. J. Phys. Chem. C 2007, 111, 11390-11396. [CrossRef]

193. Zezza, F.; Comparelli, R.; Striccoli, M.; Curri, M.L.; Tommasi, R.; Agostiano, A.; Della Monica, M. High quality CdS nanocrystals: Surface effects. Synth. Met. 2003, 139, 597-600. [CrossRef]

194. Fini, P.; Depalo, N.; Comparelli, R.; Curri, M.L.; Striccoli, M.; Castagnolo, M.; Agostiano, A. Interactions between surfactant capped CdS nanocrystals and organic solvent. J. Therm. Anal. Calorim. 2008, 92, 271-277. [CrossRef]

195. Ingrosso, C.; Panniello, A.; Comparelli, R.; Curri, M.L.; Striccoli, M. Colloidal Inorganic Nanocrystal Based Nanocomposites: Functional Materials for Micro and Nanofabrication. Materials 2010, 3, 1316-1352. [CrossRef]

196. Curri, M.L.; Comparelli, R.; Striccoli, M.; Agostiano, A. Emerging methods for fabricating functional structures by patterning and assembling engineered nanocrystals. Phys. Chem. Chem. Phys. 2010, 12, 11197-11207. [CrossRef] [PubMed]

197. Altomare, M.; Fanizza, E.; Corricelli, M.; Comparelli, R.; Striccoli, M.; Curri, M.L. Patterned assembly of luminescent nanocrystals: Role of the molecular chemistry at the interface. J. Nanoparticle Res. 2014, 16, 2468. [CrossRef]

198. Corricelli, M.; Comparelli, R.; Depalo, N.; Fanizza, E.; Sadhu, V.B.; Huskens, J.; Agostiano, A.; Striccoli, M.; Curri, M.L. Surface Functionalized Luminescent Nanocrystals Electrostatically Assembled onto a Patterned Substrate. Curr. Nanosci. 2016, 12, 386-395. [CrossRef]

199. Buonsanti, R.; Grillo, V.; Carlino, E.; Giannini, C.; Curri, M.L.; Innocenti, C.; Sangregorio, C.; Achterhold, K.; Parak, F.G.; Agostiano, A.; et al. Seeded growth of asymmetric binary nanocrystals made of a semiconductor $\mathrm{TiO}_{2}$ rodlike section and a magnetic gamma-Fe $\mathrm{O}_{3}$ spherical domain. J. Am. Chem. Soc. 2006, 128, 16953-16970. [CrossRef] [PubMed]

200. Cozzoli, P.D. Advanced Wet-Chemical Synthetic Approaches to Inorganic Nanostructures; Transworld Research Network: Kerala, India, 2008; p. 453.

201. Cozzoli, P.D.; Kornowski, A.; Weller, H. Colloidal synthesis of organic-capped ZnO nanocrystals via a sequential reduction-oxidation reaction. J. Phys. Chem. B 2005, 109, 2638-2644. [CrossRef] [PubMed]

202. Cozzoli, P.D.; Manna, L. Synthetic strategies to size and shape controlled nanocrystals and nanocrystal heterostructures. In Bio-Applications of Nanoparticles; Chan, W.C.W., Ed.; Springer: New York, NY, USA, 2007; Volume 620, pp. 1-17.

203. Cozzoli, P.D.; Manna, L.; Curri, M.L.; Kudera, S.; Giannini, C.; Striccoli, M.; Agostiano, A. Shape and phase control of colloidal ZnSe nanocrystals. Chem. Mater. 2005, 17, 1296-1306. [CrossRef] 
204. Cozzoli, P.D.; Snoeck, E.; Garcia, M.A.; Giannini, C.; Guagliardi, A.; Cervellino, A.; Gozzo, F.; Hernando, A.; Achterhold, K.; Ciobanu, N.; et al. Colloidal synthesis and characterization of tetrapod-shaped magnetic nanocrystals. Nano Lett. 2006, 6, 1966-1972. [CrossRef] [PubMed]

205. Pileni, M.P.; Cozzoli, P.D.; Pinna, N. Self-assembled supracrystals and hetero-structures made from colloidal nanocrystals. CrystEngComm 2014, 16, 9365-9367. [CrossRef]

206. Kolny-Olesiak, J.; Weller, H. Synthesis and Application of Colloidal CuInS 2 Semiconductor Nanocrystals. ACS Appl. Mater. Interfaces 2013, 5, 12221-12237. [CrossRef] [PubMed]

207. Weller, H. Synthesis and self-assembly of colloidal nanoparticles. Philos. Trans. R. Soc. Lond. Ser. A 2003, 361, 229-240. [CrossRef] [PubMed]

208. Weller, H. Quantum size colloids: From size-dependent properties of discrete particles to self-organized superstructures. Curr. Opin. Colloid Interface Sci. 1998, 3, 194-199. [CrossRef]

209. Weller, H. Colloidal semiconductor Q-particles: Chemistry in the transition region between solid and molecular states. Angew. Chem. Int. Ed. 1993, 32, 41-53. [CrossRef]

210. Alivisatos, A.P. Semiconductor Clusters, Nanocrystals, and Quantum Dots. Science 1996, $271,933-937$. [CrossRef]

211. Anderson, N.C.; Hendricks, M.P.; Choi, J.J.; Owen, J.S. Ligand Exchange and the Stoichiometry of Metal Chalcogenide Nanocrystals: Spectroscopic Observation of Facile Metal-Carboxylate Displacement and Binding. J. Am. Chem. Soc. 2013, 135, 18536-18548. [CrossRef] [PubMed]

212. Antonietti, M.; Niederberger, M.; Smarsly, B. Self-assembly in inorganic and hybrid systems: Beyond the molecular scale. Dalton Trans. 2008, 18-24. [CrossRef]

213. Bai, F.; Wang, D.; Huo, Z.; Chen, W.; Liu, L.; Liang, X.; Chen, C.; Wang, X.; Peng, Q.; Li, Y. A Versatile Bottom-up Assembly Approach to Colloidal Spheres from Nanocrystals. Angew. Chem. Int. Ed. 2007, 46, 6650-6653. [CrossRef] [PubMed]

214. Bealing, C.R.; Baumgardner, W.J.; Choi, J.J.; Hanrath, T.; Hennig, R.G. Predicting Nanocrystal Shape through Consideration of Surface-Ligand Interactions. ACS Nano 2012, 6, 2118-2127. [CrossRef] [PubMed]

215. Bruchez, M., Jr. Semiconductor Nanocrystals as Fluorescent Biological Labels. Science 1998, 281, $2013-2016$. [CrossRef] [PubMed]

216. Brus, L. Noble Metal Nanocrystals: Plasmon Electron Transfer Photochemistry and Single-Molecule Raman Spectroscopy. Acc. Chem. Res. 2008, 41, 1742-1749. [CrossRef] [PubMed]

217. Cademartiri, L.; Kitaev, V. On the nature and importance of the transition between molecules and nanocrystals: Towards a chemistry of "nanoscale perfection". Nanoscale 2011, 3, 3435-3446. [CrossRef] [PubMed]

218. Casavola, M.; Buonsanti, R.; Caputo, G.; Cozzoli, P.D. Colloidal strategies for preparing oxide-based hybrid nanocrystals. Eur. J. Inorg. Chem. 2008, 2008, 837-854. [CrossRef]

219. Comin, A.; Manna, L. New materials for tunable plasmonic colloidal nanocrystals. Chem. Soc. Rev. 2014, 43, 3957-3975. [CrossRef] [PubMed]

220. Conde, J.; Dias, J.T.; Grazú, V.; Moros, M.; Baptista, P.V.; De La Fuente, J.M. Revisiting 30 years of Biofunctionalization and Surface Chemistry of Inorganic Nanoparticles for Nanomedicine. Front. Chem. 2014, 2. [CrossRef] [PubMed]

221. Courty, A.; Fermon, C.; Pileni, M.P. “Supra crystals” made of nanocrystals. Adv. Mater. 2001, 13, $254-258$. [CrossRef]

222. De Roo, J.; Baquero, E.A.; Coppel, Y.; De Keukeleere, K.; Van Driessche, I.; Nayral, C.; Hens, Z.; Delpech, F. Insights into the Ligand Shell, Coordination Mode, and Reactivity of Carboxylic Acid Capped Metal Oxide Nanocrystals. Chempluschem 2016, 81, 1216-1223. [CrossRef]

223. Fu, A.; Gu, W.; Larabell, C.; Alivisatos, A.P. Semiconductor nanocrystals for biological imaging. Curr. Opin. Neurobiol. 2005, 15, 568-575. [CrossRef] [PubMed]

224. Gaponik, N.; Eychmueller, A. Colloidal nanocrystals. On the way from synthesis to applications. Proc. SPIE Int. Soc. Opt. Eng. 2007, 6785, M7850.

225. Gomez, D.E.; Califano, M.; Mulvaney, P. Optical properties of single semiconductor nanocrystals. Phys. Chem. Chem. Phys. 2006, 8, 4989-5011. [CrossRef] [PubMed]

226. Leite, E.R. Nanocrystals assembled from the bottom up. In Encyclopedia of Nanoscience and Nanotechnology; Nalwa, H.S., Ed.; American Scientific Publishers: Stevenson Ranch, CA, USA, 2004; Volume 6, pp. 537-554. 
227. Motte, L.; Courty, A.; Anh-Tu, N.; Lisiecki, I.; Pileni, M.-P. Self-Organization of Inorganic Nanocrystals. Nanocryst. Form. Mesoscopic Struct. 2006, 1-47. [CrossRef]

228. Niu, W.X.; Xu, G.B. Crystallographic control of noble metal nanocrystals. Nano Today 2011, 6, $265-285$. [CrossRef]

229. Parak, W.J.; Gerion, D.; Pellegrino, T.; Zanchet, D.; Micheel, C.; Williams, S.C.; Boudreau, R.; Le, G.M.A.; Larabell, C.A.; Alivisatos, A.P. Biological applications of colloidal nanocrystals. Nanotechnology 2003, 14, R15-R27. [CrossRef]

230. Pileni, M.P. Supracrystals of Inorganic Nanocrystals: An Open Challenge for New Physical Properties. Acc. Chem. Res. 2008, 41, 1799-1809. [CrossRef] [PubMed]

231. Pileni, M.P. Self-organization of inorganic nanocrystals. J. Phys. Condens. Matter 2006, 18, S67-S84. [CrossRef]

232. Pileni, M.P. Nanocrystals: Fabrication, organization and collective properties. Comptes Rendus Chim. 2003, 6, 965-978. [CrossRef]

233. Pileni, M.P. Nanocrystals: Size and Shape Control; IOS Press: Amsterdam, The Netherlands, 2003; pp. 25-31.

234. Pileni, M.P. Semiconductor Nanocrystals. In Nanoscale Materials in Chemistry; Klabunde, K.J., Ed.; Wiley VCH: Weinheim, Germany, 2001; pp. 61-84.

235. Pileni, M.P. Nanocrystals. In The Chemistry of Nanostructured Material; Yang, P., Ed.; World Scientific Publishing Co. Pte. Ltd.: Singapore, 2003; pp. 127-146.

236. Pileni, M.P. Self-assembly of inorganic nanocrystals: Fabrication and collective intrinsic properties. Acc. Chem. Res. 2007, 40, 685-693. [CrossRef] [PubMed]

237. Pileni, M.P. Self assembly of inorganic nanocrystals in 3D supra crystals: Intrinsic properties. Surf. Sci. 2009, 603, 1498-1505. [CrossRef]

238. Pileni, M.P.; Lalatonne, Y.; Ingert, D.; Lisiecki, I.; Courty, A. Self assemblies of nanocrystals: Preparation, collective properties and uses. Faraday Discuss. 2004, 125, 251-264. [CrossRef] [PubMed]

239. Polarz, S. Shape Matters: Anisotropy of the Morphology of Inorganic Colloidal Particles-Synthesis and Function. Adv. Funct. Mater. 2011, 21, 3214-3230. [CrossRef]

240. Pradhan, N.; Reifsnyder, D.; Xie, R.G.; Aldana, J.; Peng, X.G. Surface ligand dynamics in growth of nanocrystals. J. Am. Chem. Soc. 2007, 129, 9500-9509. [CrossRef] [PubMed]

241. Rogach, A.L.; Talapin, D.V.; Weller, H. Semiconductor Nanoparticles; Wiley-VCH Verlag GmbH \& Co. KGaA: Weinheim, Germany, 2004; pp. 52-95.

242. Scher, E.C.; Manna, L.; Alivisatos, A.P. Shape control and applications of nanocrystals. Philos. Trans. R. Soc. Lond. Ser. A 2003, 361, 241-257. [CrossRef] [PubMed]

243. Shavel, A.; Gaponik, N.; Eychmueller, A. The assembling of semiconductor nanocrystals. Eur. J. Inorg. Chem. 2005, 3613-3623. [CrossRef]

244. Van Embden, J.; Chesman, A.S.R.; Jasieniak, J.J. The Heat-Up Synthesis of Colloidal Nanocrystals. Chem. Mater. 2015, 27, 2246-2285. [CrossRef]

245. Wang, X.; Zhuang, J.; Peng, Q.; Li, Y. A general strategy for nanocrystal synthesis. Nature 2005, 437, $121-124$. [CrossRef] [PubMed]

246. Yin, Y.; Alivisatos, A.P. Colloidal nanocrystal synthesis and the organic-inorganic interface. Nature 2005, 437, 664-670. [CrossRef] [PubMed]

247. Yuan, Q.; Wang, X. Aqueous-based route toward noble metal nanocrystals: Morphology-controlled synthesis and their applications. Nanoscale 2010, 2, 2328-2335. [CrossRef] [PubMed]

248. Weller, H. Quantized semiconductor particles: A novel state of matter for materials science. Adv. Mater. 1993, 5, 88-95. [CrossRef]

249. Weller, H. Colloidal semiconductor Q-particles: Chemistry in the transition between solid-state and molecules. Angew. Chem.-Int. Ed. Engl. 1993, 32, 41-53. [CrossRef]

250. De Roo, J.; De Keukeleere, K.; Hens, Z.; Van Driessche, I. From ligands to binding motifs and beyond; the enhanced versatility of nanocrystal surfaces. Dalton Trans. 2016, 45, 13277-13283. [CrossRef] [PubMed]

251. De Roo, J.; Van den Broeck, F.; De Keukeleere, K.; Martins, J.C.; Van Driessche, I.; Hens, Z. Unravelling the Surface Chemistry of Metal Oxide Nanocrystals, the Role of Acids and Bases. J. Am. Chem. Soc. 2014, 136, 9650-9657. [CrossRef] [PubMed]

252. Grisorio, R.; Debellis, D.; Suranna, G.P.; Gigli, G.; Giansante, C. The Dynamic Organic/Inorganic Interface of Colloidal PbS Quantum Dots. Angew. Chem.-Int. Ed. 2016, 55, 6626-6632. 
253. Hens, Z.; Martins, J.C. A Solution NMR Toolbox for Characterizing the Surface Chemistry of Colloidal Nanocrystals. Chem. Mater. 2013, 25, 1211-1221. [CrossRef]

254. Hens, Z.; Van den Broeck, F.; De Roo, J.; Dierick, R.; Van Driessche, I.; Martins, J.C. Surface Chemistry of Colloidal Nanocrystals-From Semiconductors to Metal Oxides. In Abstracts of Papers of the American Chemical Society. VOL. 248. 1155 16TH ST, NW; Amer. Chemical Soc.: Washington, DC, USA, 2014.

255. Mews, A. Surface chemistry of semiconductor nanocrystals. Z. Phys. Chem. 2007, 221, 295-306. [CrossRef]

256. Wu, B.; Zheng, N. Surface and interface control of noble metal nanocrystals for catalytic and electrocatalytic applications. Nano Today 2013, 8, 168-197. [CrossRef]

257. Beaulac, R.; Ochsenbein, S.T.; Gamelin, D.R. Colloidal transition-metal-doped quantum dots. In Nanocrystal Quantum Dots; Klimov, V.I., Ed.; Taylor \& Francis: New York, NY, USA, 2010; p. 397.

258. Clift, M.J.D.; Stone, V. Quantum Dots: An Insight and Perspective of Their Biological Interaction and How This Relates to Their Relevance for Clinical Use. Theranostics 2012, 2, 668-680. [CrossRef] [PubMed]

259. De Roo, J.; Van Driessche, I.; Martins, J.C.; Hens, Z. Colloidal metal oxide nanocrystal catalysis by sustained chemically driven ligand displacement. Nat. Mater. 2016, 15, 517-521. [CrossRef] [PubMed]

260. Maillard, M.; Motte, L.; Pileni, M.P. Rings and hexagons made of nanocrystals. Adv. Mater. 2001, 13, $200-204$. [CrossRef]

261. Capetti, E.; Ferretti, A.M.; Dal Santo, V.; Ponti, A. Surfactant-controlled composition and crystal structure of manganese(II) sulfide nanocrystals prepared by solvothermal synthesis. Beilstein J. Nanotechnol. 2015, 6, 2319-2329. [CrossRef] [PubMed]

262. De Queiroz, A.A.A.; Martins, M.; Soares, D.A.W.; França, É.J. Modeling of ZnS quantum dots synthesis by DFT techniques. J. Mol. Struct. 2008, 873, 121-129. [CrossRef]

263. Garcia-Rodriguez, R.; Hendricks, M.P.; Cossairt, B.M.; Liu, H.T.; Owen, J.S. Conversion Reactions of Cadmium Chalcogenide Nanocrystal Precursors. Chem. Mater. 2013, 25, 1233-1249. [CrossRef]

264. Kolny-Olesiak, J. Synthesis of copper sulphide-based hybrid nanostructures and their application in shape control of colloidal semiconductor nanocrystals. Crystengcomm 2014, 16, 9381-9390. [CrossRef]

265. Sweeney, R.Y.; Mao, C.; Gao, X.; Burt, J.L.; Belcher, A.M.; Georgiou, G.; Iverson, B.L. Bacterial Biosynthesis of Cadmium Sulfide Nanocrystals. Chem. Biol. 2004, 11, 1553-1559. [CrossRef] [PubMed]

266. Armelao, L.; Bertagnolli, H.; Gross, S.; Krishnan, V.; Lavrencic-Stangar, U.; Mueller, K.; Orel, B.; Srinivasan, G.; Tondello, E.; Zattin, A. Zr and Hf oxoclusters as building blocks for the preparation of nanostructured hybrid materials and binary oxides $\mathrm{MO}_{2}-\mathrm{SiO}_{2}(\mathrm{M}=\mathrm{Hf}, \mathrm{Zr})$. J. Mater. Chem. 2005, 15, 1954-1965. [CrossRef]

267. Patel, J.D.; Mighri, F.; Ajji, A. Generalized chemical route to develop fatty acid capped highly dispersed semiconducting metal sulphide nanocrystals. Mater. Res. Bull. 2012, 47, 2016-2021. [CrossRef]

268. Bae, S.; Mannan, M.B.; Lee, W. Adsorption of cationic cetylpyridinium chloride on pyrite surface. J. Ind. Eng. Chem. 2012, 18, 1482-1488. [CrossRef]

269. Henglein, A. Colloidal silver nanoparticles: Photochemical preparation and interaction with $\mathrm{O}-2, \mathrm{CCl}_{4}$, and some metal ions. Chem. Mater. 1998, 10, 444-450. [CrossRef]

270. Henglein, A.; Fojtik, A.; Weller, H. Reactions on colloidal semiconductor particles. Ber. Bunsen-Ges. Phys. Chem. 1987, 91, 441-446. [CrossRef]

271. Wang, M.; Zhang, Q.; Hao, W.; Sun, Z.-X. Surface stoichiometry of zinc sulfide and its effect on the adsorption behaviors of xanthate. Chem. Cent. J. 2011, 5, 73. [CrossRef] [PubMed]

272. Wang, X.; Shi, J.; Feng, Z.; Li, M.; Li, C. Visible emission characteristics from different defects of ZnS nanocrystals. Phys. Chem. Chem. Phys. PCCP 2011, 13, 4715-4723. [CrossRef] [PubMed]

273. Zhang, H.; Huang, F.; Gilbert, B.; Banfield, J.F. Molecular Dynamics Simulations, Thermodynamic Analysis, and Experimental Study of Phase Stability of Zinc Sulfide Nanoparticles. J. Phys. Chem. B 2003, 107, 13051-13060. [CrossRef]

274. Moreels, I.; Justo, Y.; De Geyter, B.; Haustraete, K.; Martins, J.C.; Hens, Z. Size-Tunable, Bright, and Stable PbS Quantum Dots: A Surface Chemistry Study. ACS Nano 2011, 5, 2004-2012. [CrossRef] [PubMed]

275. De Roo, J.; Justo, Y.; De Keukeleere, K.; Van den Broeck, F.; Martins, J.C.; Van Driessche, I.; Hens, Z. Carboxylic-Acid-Passivated Metal Oxide Nanocrystals: Ligand Exchange Characteristics of a New Binding Motif. Angew. Chem. Int. Ed. 2015, 54, 6488-6491. [CrossRef] [PubMed]

276. Erathodiyil, N.; Ying, J.Y. Functionalization of Inorganic Nanoparticles for Bioimaging Applications. Acc. Chem. Res. 2011, 44, 925-935. [CrossRef] [PubMed] 
277. Ling, D.S.; Hackett, M.J.; Hyeon, T. Surface ligands in synthesis, modification, assembly and biomedical applications of nanoparticles. Nano Today 2014, 9, 457-477. [CrossRef]

278. Lü, C.; Gao, J.; Fu, Y.; Du, Y.; Shi, Y.; Su, Z. A Ligand Exchange Route to Highly Luminescent Surface-Functionalized ZnS Nanoparticles and Their Transparent Polymer Nanocomposites. Adv. Funct. Mater. 2008, 18, 3070-3079. [CrossRef]

279. Nag, A.; Zhang, H.; Janke, E.; Talapin, D.V. Inorganic Surface Ligands for Colloidal Nanomaterials. Z. Phys. Chem. 2015, 229, 85-107. [CrossRef]

280. Smolensky, E.D.; Park, H.Y.E.; Berquó, T.S.; Pierre, V.C. Surface functionalization of magnetic iron oxide nanoparticles for MRI applications_Effect of anchoring group and ligand exchange protocol. Contrast Media Mol. Imaging 2011, 6, 189-199. [CrossRef] [PubMed]

281. Wang, X.Y.; Tilley, R.D.; Watkins, J.J. Simple Ligand Exchange Reactions Enabling Excellent Dispersibility and Stability of Magnetic Nanoparticles in Polar Organic, Aromatic, and Protic Solvents. Langmuir 2014, 30, 1514-1521. [CrossRef] [PubMed]

282. Du, Y.Y.; Yang, P.; Matras-Postolek, K.; Wang, J.P.; Che, Q.D.; Cao, Y.Q.; Ma, Q. Low toxic and highly

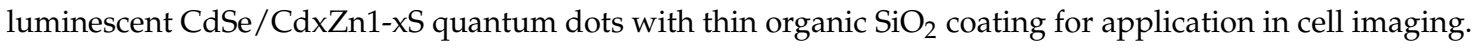
J. Nanopart. Res. 2016, 18, 37. [CrossRef]

283. Morgese, G.; Causin, V.; Maggini, M.; Corra, S.; Gross, S.; Benetti, E.M. Ultrastable Suspensions of Polyoxazoline-Functionalized ZnO Single Nanocrystals. Chem. Mater. 2015, 27, 2957-2964. [CrossRef]

284. Amiens, C.; Ciuculescu-Pradines, D.; Philippot, K. Controlled metal nanostructures: Fertile ground for coordination chemists. Coord. Chem. Rev. 2016, 308, 409-432. [CrossRef]

285. Ma, M.-G.; Cölfen, H. Mesocrystals-Applications and potential. Curr. Opin. Colloid Interface Sci. 2014, 19, 56-65. [CrossRef]

286. Choi, J.J.; Bealing, C.R.; Bian, K.F.; Hughes, K.J.; Zhang, W.Y.; Smilgies, D.M.; Hennig, R.G.; Engstrom, J.R.; Hanrath, T. Controlling Nanocrystal Superlattice Symmetry and Shape-Anisotropic Interactions through Variable Ligand Surface Coverage. J. Am. Chem. Soc. 2011, 133, 3131-3138. [CrossRef] [PubMed]

287. Green, M.L.H. A new approach to the formal classification of covalent compounds of the elements. J. Organomet. Chem. 1995, 500, 127-148. [CrossRef]

288. Douglas, R.N.; Williamson, C.B.; Hanrath, T.; Robinson, R.D. Surface chemistry of cadmium sulfide magic-sized clusters: A window into ligand-nanoparticle interactions. Chem. Commun. 2017. [CrossRef]

289. Cölfen, H. Double-hydrophilic block copolymers: Synthesis and application as novel surfactants and crystal growth modifiers. Macromol. Rapid Commun. 2001, 22, 219-252. [CrossRef]

290. Cölfen, H. Polymer-Mediated Growth of Crystals and Mesocrystals. In Research Methods in Biomineralization Science; Yoreo, J.J.D., Ed.; Elsevier Science Publishing Co., Inc.: New York, NY, USA, 2013; Volume 532, pp. 277-304.

291. Cölfen, H.; Antonietti, M. Mesocrystals: Inorganic superstructures made by highly parallel crystallization and controlled alignment. Angew. Chem. Int. Edit. 2005, 44, 5576-5591. [CrossRef] [PubMed]

292. Niederberger, M.; Garnweitner, G.; Krumeich, F.; Nesper, R.; Cölfen, H.; Antonietti, M. Tailoring the Surface and Solubility Properties of Nanocrystalline Titania by a Nonaqueous In Situ Functionalization Process. Chem. Mater. 2004, 16, 1202-1208. [CrossRef]

293. Boncher, W.; Dalafu, H.; Rosa, N.; Stoll, S. Europium chalcogenide magnetic semiconductor nanostructures. Coord. Chem. Rev. 2015, 289, 279-288. [CrossRef]

294. Abbad, A.; Bentata, S.; Bentounes, H.A.; Benstaali, W.; Bouadjemi, B. Study of electronic and magnetic properties of binary zinc sulfide and ternary manganese- and iron-substituted alloys. Mater. Sci. Semicond. Process. 2013, 16, 576-581. [CrossRef]

295. Owens, F.J.; Gladczuk, L.; Szymczak, R.; Dluzewski, P.; Wisniewski, A.; Szymczak, H.; Golnik, A.; Bernhard, C.; Niedermayer, C. High temperature magnetic order in zinc sulfide doped with copper. J. Phys. Chem. Solids 2011, 72, 648-652. [CrossRef]

296. Cardinali, M.; Valentini, L.; Fabbri, P.; Kenny, J.M. Radiofrequency plasma assisted exfoliation and reduction of large-area graphene oxide platelets produced by a mechanical transfer process. Chem. Phys. Lett. 2011, 508, 285-288. [CrossRef]

297. Baruah, S.; Ortinero, C.; Shipin, O.V.; Dutta, J. Manganese Doped Zinc Sulfide Quantum Dots for Detection of Escherichia coli. J. Fluoresc. 2012, 22, 403-408. [CrossRef] [PubMed] 
298. Sluydts, M.; De Nolf, K.; Van Speybroeck, V.; Cottenier, S.; Hens, Z. Ligand Addition Energies and the Stoichiometry of Colloidal Nanocrystals. ACS Nano 2016, 10, 1462-1474. [CrossRef] [PubMed]

299. Manzoor, K.; Johny, S.; Thomas, D.; Setua, S.; Menon, D.; Nair, S. Bio-conjugated luminescent quantum dots of doped ZnS: A cyto-friendly system for targeted cancer imaging. Nanotechnology 2009, 20, 065102. [CrossRef] [PubMed]

300. Mathew, M.E.; Mohan, J.C.; Manzoor, K.; Nair, S.V.; Tamura, H.; Jayakumar, R. Folate conjugated carboxymethyl chitosan-Manganese doped zinc sulphide nanoparticles for targeted drug delivery and imaging of cancer cells. Carbohydr. Polym. 2010, 80, 442-448. [CrossRef]

301. Armelao, L.; Camozzo, D.; Gross, S.; Tondello, E. Embedding of electroluminescent ZnS:Cu phosphors in PMMA matrix by polymerization of particle suspension in MMA monomer. J. Non-Cryst. Solids 2004, 345-346, 402-406. [CrossRef]

302. Hu, H.; Zhang, W. Synthesis and properties of transition metals and rare-earth metals doped ZnS nanoparticles. Opt. Mater. 2006, 28, 536-550. [CrossRef]

303. Da Silva, A.R.; Aucelio, R.Q.; Rodriguez-Cotto, R.I.; Ortiz-Martinez, M.G.; Rivera-Ramirez, E.; Frias, D.P.; Macchione, M.; Jimenez-Velez, B.; Gioda, A. Physicochemical properties and toxicological assessment of modified CdS nanoparticles. J. Nanopart. Res. 2014, 16, 2655. [CrossRef]

304. Derfus, A.M.; Chan, W.C.W.; Bhatia, S.N. Probing the Cytotoxicity of Semiconductor Quantum Dots. Nano Lett. 2004, 4, 11-18. [CrossRef]

305. Hossain, S.T.; Das, P.; Mukherjee, S.K. Toxicity of cadmium nanoparticles to Bacillus subtilis. Toxicol. Environ. Chem. 2013, 95, 1748-1756. [CrossRef]

306. Li, H.; Li, M.Y.; Shih, W.Y.; Lelkes, P.I.; Shih, W.H. Cytotoxicity Tests of Water Soluble ZnS and CdS Quantum Dots. J. Nanosci. Nanotechnol. 2011, 11, 3543-3551. [CrossRef] [PubMed]

307. Li, Z.B.; Cai, W.; Chen, X.Y. Semiconductor quantum dots for in vivo imaging. J. Nanosci. Nanotechnol. 2007, 7, 2567-2581. [CrossRef] [PubMed]

308. Murray, C.B.; Norris, D.J.; Bawendi, M.G. Synthesis and characterization of nearly monodisperse CdE (E = sulfur, selenium, tellurium) semiconductor nanocrystallites. J. Am. Chem. Soc. 1993, 115, 8706-8715. [CrossRef]

309. Su, Y.; Peng, F.; Jiang, Z.; Zhong, Y.; Lu, Y.; Jiang, X.; Huang, Q.; Fan, C.; Lee, S.-T.; He, Y. In vivo distribution, pharmacokinetics, and toxicity of aqueous synthesized cadmium-containing quantum dots. Biomaterials 2011, 32, 5855-5862. [CrossRef] [PubMed]

310. Zhang, L.S.W.; Baumer, W.; Monteiro-Riviere, N.A. Cellular uptake mechanisms and toxicity of quantum dots in dendritic cells. Nanomedicine 2011, 6, 777-791. [CrossRef] [PubMed]

311. Zhang, L.W.; Monteiro-Riviere, N.A. Mechanisms of Quantum Dot Nanoparticle Cellular Uptake. Toxicol. Sci. 2009, 110, 138-155. [CrossRef] [PubMed]

312. Feng, W.; Nie, W.; Cheng, Y.H.; Zhou, X.J.; Chen, L.; Qiu, K.X.; Chen, Z.G.; Zhu, M.F.; He, C.L. In vitro and in vivo toxicity studies of copper sulfide nanoplates for potential photothermal applications. Nanomed. Nanotechnol. Biol. Med. 2015, 11, 901-912. [CrossRef] [PubMed]

313. Tan, X.X.; Pang, X.J.; Lei, M.Z.; Ma, M.; Guo, F.; Wang, J.P.; Yu, M.; Tan, F.P.; Li, N. An efficient dual-loaded multifunctional nanocarrier for combined photothermal and photodynamic therapy based on copper sulfide and chlorin e6. Int. J. Pharm. 2016, 503, 220-228. [CrossRef] [PubMed]

314. Grozdanov, I.; Najdoski, M. Optical and Electrical Properties of Copper Sulfide Films of Variable Composition. J. Solid State Chem. 1995, 114, 469-475. [CrossRef]

315. Öztaş, M.; Bedir, M.; Necmeddin Yazici, A.; Vural Kafadar, E.; Toktamış, H. Characterization of copper-doped sprayed ZnS thin films. Phys. B 2006, 381, 40-46. [CrossRef]

316. Sperling, R.A.; Parak, W.J. Surface modification, functionalization and bioconjugation of colloidal inorganic nanoparticles. Ther. Innov. Regul. Sci. 2013, 47, 1333-1383. [CrossRef] [PubMed]

317. Kim, K.-S. Functionalization of magnetic nanoparticles for biomedical applications. Korean J. Chem. Eng. 2014, 31, 1289-1305.

318. Sapsford, K.E.; Algar, W.R.; Berti, L.; Gemmill, K.B.; Casey, B.J.; Oh, E.; Stewart, M.H.; Medintz, I.L. Functionalizing Nanoparticles with Biological Molecules: Developing Chemistries that Facilitate Nanotechnology. Chem. Rev. 2013, 113, 1904-2074. [CrossRef] [PubMed]

319. Feldgitscher, C.; Peterlik, H.; Puchberger, M.; Kickelbick, G. Structural Investigations on Hybrid Polymers Suitable as a Nanoparticle Precipitation Environment. Chem. Mater. 2009, 21, 695-705. [CrossRef] 
320. Otsuka, H.; Nagasaki, Y.; Kataoka, K. PEGylated nanoparticles for biological and pharmaceutical applications. Adv. Drug Deliv. Rev. 2012, 64, 246-255. [CrossRef]

321. Thiry, M.; Boldt, K.; Nikolic, M.S.; Schulz, F.; Ijeh, M.; Panicker, A.; Vossmeyer, T.; Weller, H. Fluorescence Properties of Hydrophilic Semiconductor Nanoparticles with Tridentate Polyethylene Oxide Ligands. ACS Nano 2011, 5, 4965-4973. [CrossRef] [PubMed]

322. Stenzel, M.H. Bioconjugation Using Thiols: Old Chemistry Rediscovered to Connect Polymers with Nature's Building Blocks. ACS Macro Lett. 2013, 2, 14-18. [CrossRef]

323. Ulman, A.; Kang, J.F.; Shnidman, Y.; Liao, S.; Jordan, R.; Choi, G.Y.; Zaccaro, J.; Myerson, A.S.; Rafailovich, M.; Sokolov, J.; et al. Self-assembled monolayers of rigid thiols. J. Biotechnol. 2000, 74, 175-188. [CrossRef]

324. Guarise, C.; Pasquato, L.; De Filippis, V.; Scrimin, P. Gold nanoparticles-based protease assay. Proc. Natl. Acad. Sci. USA 2006, 103, 3978-3982. [CrossRef] [PubMed]

325. Guarise, C.; Pasquato, L.; Scrimin, P. Reversible aggregation/deaggregation of gold nanoparticles induced by a cleavable dithiol linker. Langmuir 2005, 21, 5537-5541. [CrossRef] [PubMed]

326. Mancin, F.; Prins, L.J.; Scrimin, P. Catalysis on gold-nanoparticle-passivating monolayers. Curr. Opin. Colloid Interface Sci. 2013, 18, 61-69. [CrossRef]

327. Pasquato, L.; Pengo, P.; Scrimin, P. Nanozymes: Functional nanoparticle-based catalysts. Supramol. Chem. 2005, 17, 163-171. [CrossRef]

328. Di Pietro, P.; Strano, G.; Zuccarello, L.; Satriano, C. Gold and Silver Nanoparticles for Applications in Theranostics. Curr. Top. Med. Chem. 2016, 16, 3069-3102. [CrossRef]

329. Amstad, E.; Gillich, T.; Bilecka, I.; Textor, M.; Reimhult, E. Ultrastable iron oxide nanoparticle colloidal suspensions using dispersants with catechol-derived anchor groups. Nano Lett. 2009, 9, 4042-4048. [CrossRef] [PubMed]

330. Franzmann, E.; Khalil, F.; Weidmann, C.; Schröder, M.; Rohnke, M.; Janek, J.; Smarsly, B.M.; Maison, W. A biomimetic principle for the chemical modification of metal surfaces: Synthesis of tripodal catecholates as analogues of siderophores and mussel adhesion proteins. Chem. Eur. J. 2011, 17, 8596-8603. [CrossRef] [PubMed]

331. Maison, W.; Khalil, F.; Franzmann, E. New tripodal catechol derivatives having adamantyl skeleton, useful in a method for the functionalization of surfaces. 2012.

332. Huang, X.H.; Neretina, S.; El-Sayed, M.A. Gold Nanorods: From Synthesis and Properties to Biological and Biomedical Applications. Adv. Mater. 2009, 21, 4880-4910. [CrossRef] [PubMed]

333. Jain, P.K.; Huang, X.; El-Sayed, I.H.; El-Sayed, M.A. Noble Metals on the Nanoscale: Optical and Photothermal Properties and Some Applications in Imaging, Sensing, Biology, and Medicine. Acc. Chem. Res. 2008, 41, 1578-1586. [CrossRef] [PubMed]

334. Alexandridis, P. Gold Nanoparticle Synthesis, Morphology Control, and Stabilization Facilitated by Functional Polymers. Chem. Eng. Technol. 2011, 34, 15-28. [CrossRef]

335. Alkilany, A.M.; Lohse, S.E.; Murphy, C.J. The Gold Standard: Gold Nanoparticle Libraries to Understand the Nano-Bio Interface. Acc. Chem. Res. 2013, 46, 650-661. [CrossRef] [PubMed]

336. Barnard, A.S.; Young, N.P.; Kirkland, A.I.; Van Huis, M.A.; Xu, H. Nanogold: A quantitative phase map. ACS Nano 2009, 3, 1431-1436. [CrossRef] [PubMed]

337. Boisselier, E.; Astruc, D. Gold nanoparticles in nanomedicine: Preparations, imaging, diagnostics, therapies and toxicity. Chem. Soc. Rev. 2009, 38, 1759-1782. [CrossRef] [PubMed]

338. Thanh, N.T.K.; Green, L.A.W. Functionalisation of nanoparticles for biomedical applications. Nano Today 2010, 5, 213-230. [CrossRef]

339. Cao-Milan, R.; Liz-Marzan, L.M. Gold nanoparticle conjugates: Recent advances toward clinical applications. Expert Opin. Drug Del. 2014, 11, 741-752. [CrossRef] [PubMed]

340. Daniel, M.C.; Astruc, D. Gold Nanoparticles: Assembly, Supramolecular Chemistry, Quantum-Size-Related Properties, and Applications toward Biology, Catalysis, and Nanotechnology. Chem. Rev. 2004, 104, $293-346$. [CrossRef] [PubMed]

341. Gross, S. Colloidal Dispersions of Gold Nanoparticles (Invited Chapter). In Materials Syntheses; Springer Verlag: Wien, Austria, 2008; Volume 1.

342. Grzelczak, M.; Perez-Juste, J.; Mulvaney, P.; Liz-Marzan, L.M. Shape control in gold nanoparticle synthesis. Chem. Soc. Rev. 2008, 37, 1783-1791. [CrossRef] [PubMed] 
343. Li, N.; Zhao, P.; Astruc, D. Anisotropic Gold Nanoparticles: Synthesis, Properties, Applications, and Toxicity. Angew. Chem. Int. Ed. 2014, 53, 1756-1789. [CrossRef] [PubMed]

344. Narayanan, K.B.; Sakthivel, N. Biological synthesis of metal nanoparticles by microbes. Adv. Colloid Interface Sci. 2010, 156, 1-13. [CrossRef] [PubMed]

345. Pasquato, L.; Pengo, P.; Scrimin, P. Functional gold nanoparticles for recognition and catalysis. J. Mater. Chem. 2004, 14, 3481-3487. [CrossRef]

346. Sharma, P.; Brown, S.; Walter, G.; Santra, S.; Moudgil, B. Nanoparticles for bioimaging. Adv. Colloid Interface Sci. 2006, 123-126, 471-485. [CrossRef] [PubMed]

347. Ayyad, O.; Munoz-Rojas, D.; Oro-Sole, J.; Gomez-Romero, P. From silver nanoparticles to nanostructures through matrix chemistry. J. Nanoparticle Res. 2010, 12, 337-345. [CrossRef]

348. Colomban, P. The Use of Metal Nanoparticles to Produce Yellow, Red and Iridescent Colour, from Bronze Age to Present Times in Lustre Pottery and Glass: Solid State Chemistry, Spectroscopy and Nanostructure. J. Nano Res. 2009, 8, 109-132. [CrossRef]

349. Ghaffari-Moghaddam, M.; Hadi-Dabanlou, R.; Khajeh, M.; Rakhshanipour, M.; Shameli, K. Green synthesis of silver nanoparticles using plant extracts. Korean J. Chem. Eng. 2014, 31, 548-557. [CrossRef]

350. Grancaric, A.M.; Rybicki, E.; Tarbuk, A.; Pavlovic, G.; Botteri, L. Nanoparticles of silver in antimicrobial treatment of textiles. Tekstil 2011, 60, 629-639.

351. Henglein, A. Chemisorption effects on colloidal lead nanoparticles. J. Phys. Chem. B 1999, 103, $9302-9305$. [CrossRef]

352. Henglein, A.; Giersig, M. Formation of colloidal silver nanoparticles: Capping action of citrate. J. Phys. Chem. B 1999, 103, 9533-9539. [CrossRef]

353. Le Ouay, B.; Stellacci, F. Antibacterial activity of silver nanoparticles: A surface science insight. Nano Today 2015, 10, 339-354. [CrossRef]

354. Liz-Marzan, L.M. Tailoring surface plasmons through the morphology and assembly of metal nanoparticles. Langmuir 2006, 22, 32-41. [CrossRef] [PubMed]

355. Mittal, A.K.; Chisti, Y.; Banerjee, U.C. Synthesis of metallic nanoparticles using plant extracts. Biotechnol. Adv. 2013, 31, 346-356. [CrossRef] [PubMed]

356. Narayanan, K.B.; Sakthivel, N. Green synthesis of biogenic metal nanoparticles by terrestrial and aquatic phototrophic and heterotrophic eukaryotes and biocompatible agents. Adv. Colloid Interface Sci. 2011, 169, 59-79. [CrossRef] [PubMed]

357. Padmos, J.D.; Zhang, P. Surface Structure of Organosulfur Stabilized Silver Nanoparticles Studied with X-ray Absorption Spectroscopy. J. Phys. Chem. C 2012, 116, 23094-23101. [CrossRef]

358. Pastoriza-Santos, I.; Liz-Marzan, L.M. Formation and stabilization of silver nanoparticles through reduction by $N, N$-dimethylformamide. Langmuir 1999, 15, 948-951. [CrossRef]

359. Pastoriza-Santos, I.; Liz-Marzan, L.M. Colloidal silver nanoplates. State of the art and future challenges. J. Mater. Chem. 2008, 18, 1724-1737. [CrossRef]

360. Pileni, M.P. Fabrication and physical properties of self-organized silver nanocrystals. Pure Appl. Chem. 2000, 72, 53-65. [CrossRef]

361. Pileni, M.P. Colloidal self-assemblies used as templates to control size, shape and self-organization of nanoparticles. Supramol. Sci. 1998, 5, 321-329. [CrossRef]

362. Pileni, M.P.; Taleb, A.; Petit, C. Silver metal nanosized particles: Control of particle size, self assemblies in 2D and 3D superlattices and optical properties. J Dispers. Sci. Technol. 1998, 19, 185-206. [CrossRef]

363. Quester, K.; Avalos-Borja, M.; Castro-Longoria, E. Biosynthesis and microscopic study of metallic nanoparticles. Micron 2013, 54-55, 1-27. [CrossRef] [PubMed]

364. Rai, M.; Deshmukh, S.D.; Ingle, A.P.; Gupta, I.R.; Galdiero, M.; Galdiero, S. Metal nanoparticles: The protective nanoshield against virus infection. Crit. Rev. Microbiol. 2016, 42, 46-56. [CrossRef] [PubMed]

365. Sarkar, A.; Kapoor, S.; Mukherjee, T. Synthesis and characterisation of silver nanoparticles in viscous solvents and its transfer into non-polar solvents. Res. Chem. Intermed. 2010, 36, 411-421. [CrossRef]

366. Stamplecoskie, K.G.; Scaiano, J.C. Silver as an Example of the Applications of Photochemistry to the Synthesis and Uses of Nanomaterials. Photochem. Photobiol. 2012, 88, 762-768. [CrossRef] [PubMed]

367. Sweet, M.J.; Chesser, A.; Singleton, I. Review: Metal-Based Nanoparticles; Size, Function, and Areas for Advancement in Applied Microbiology. In Advances in Applied Microbiology; Sariaslani, S., Gadd, G.M., Eds.; Elsevier Science Publishing Co., Inc.: New York, NY, USA, 2012; Volume 80, pp. 113-142. 
368. Zhang, C.Q.; Hu, Z.Q.; Deng, B.L. Silver nanoparticles in aquatic environments: Physiochemical behavior and antimicrobial mechanisms. Water Res. 2016, 88, 403-427. [CrossRef] [PubMed]

369. Stewart, M.H.; Susumu, K.; Mei, B.C.; Medintz, I.L.; Delehanty, J.B.; Blanco-Canosa, J.B.; Dawson, P.E.; Mattoussi, H. Multidentate poly(ethylene glycol) ligands provide colloidal stability to semiconductor and metallic nanocrystals in extreme conditions. J. Am. Chem. Soc. 2010, 132, 9804-9813. [CrossRef] [PubMed]

370. Wu, P.; Yan, X.-P. Doped quantum dots for chemo/biosensing and bioimaging. Chem. Soc. Rev. 2013, 42, 5489-5521. [CrossRef] [PubMed]

371. Yao, J.; Yang, M.; Duan, Y.X. Chemistry, Biology, and Medicine of Fluorescent Nanomaterials and Related Systems: New Insights into Biosensing, Bioimaging, Genomics, Diagnostics, and Therapy. Chem. Rev. 2014, 114, 6130-6178. [CrossRef] [PubMed]

372. Deng, Z.; Tong, L.; Flores, M.; Lin, S.; Cheng, J.X.; Yan, H.; Liu, Y. High-quality manganese-doped zinc sulfide quantum rods with tunable dual-color and multiphoton emissions. J. Am. Chem. Soc. 2011, 133, 5389-5396. [CrossRef] [PubMed]

373. Kershaw, S.V.; Susha, A.S.; Rogach, A.L. Narrow bandgap colloidal metal chalcogenide quantum dots: Synthetic methods, heterostructures, assemblies, electronic and infrared optical properties. Chem. Soc. Rev. 2013, 42, 3033-3087. [CrossRef] [PubMed]

374. Kilina, S.V.; Tamukong, P.K.; Kilin, D.S. Surface Chemistry of Semiconducting Quantum Dots: Theoretical Perspectives. Acc. Chem. Res. 2016, 49, 2127-2135. [CrossRef] [PubMed]

375. Kloepfer, J.; Mielke, R. Quantum dots as strain-and metabolism-specific microbiological labels. Appl. Environ. Environ. Microbiol. 2003, 69, 4205-4213. [CrossRef]

376. Sk, M.A.; Ananthanarayanan, A.; Huang, L.; Lim, K.H.; Chen, P. Revealing the tunable photoluminescence properties of graphene quantum dots. J. Mater. Chem. C 2014, 2, 6954-6960. [CrossRef]

377. Xie, B.; Hu, R.; Luo, X.B. Quantum Dots-Converted Light-Emitting Diodes Packaging for Lighting and Display: Status and Perspectives. J. Electron. Packag. 2016, 138, 020803. [CrossRef]

378. Weissleder, R.; Mahmood, U. Molecular Imaging. Radiology 2001, 291, 316-333. [CrossRef] [PubMed]

379. Du, Z.N.; Xu, Z.Y.; Zhang, Y.C.; Zhang, M. Solvothermal Synthesis of Mn-doped CdS Nanorods Using Single-source Molecular Precursors. In Materials and Design, Pts 1-3; Sang, X.M., Wang, P.C., Ai, L., Li, Y.G., Bu, J.L., Eds.; Elsevier Publishing: New York, NY, USA, 2011; Volume 284-286, pp. 667-670.

380. Joswig, J.O.; Springborg, M.; Seifert, G. Structural and electronic properties of cadmium sulfide clusters. J. Phys. Chem. B 2000, 104, 2617-2622. [CrossRef]

381. Kozhevnikova, N.S.; Vorokh, A.S.; Uritskaya, A.A. Cadmium sulfide nanoparticles prepared by chemical bath deposition. Russ. Chem. Rev. 2015, 84, 225-250. [CrossRef]

382. Ni, T.; Nagesha, D.K.; Robles, J.; Materer, N.F.; Mussig, S.; Kotov, N.A. CdS nanoparticles modified to chalcogen sites: New supramolecular complexes, butterfly bridging, and related optical effects. J. Am. Chem. Soc. 2002, 124, 3980-3992. [CrossRef] [PubMed]

383. Sharma, R. Optical studies of CdS:Mn nanoparticles. Luminescence 2012, 27, 501-504. [CrossRef] [PubMed]

384. Singh, S.; Garg, S.; Chahal, J.; Raheja, K.; Singh, D.; Singla, M.L. Luminescent behavior of cadmium sulfide quantum dots for gallic acid estimation. Nanotechnology 2013, 24, 115602. [CrossRef] [PubMed]

385. Xu, Y.L.; Xia, J.R.; Hu, B.H. Controlled growth of CdS nanoparticles in polyurushiol matrices. Prog. Org. Coat. 2009, 65, 25-29. [CrossRef]

386. Klein, C.A.; Donadio, R.N. Infrared-active phonons in cubic zinc sulfide. J. Appl. Phys. 1980, 51, 797-800. [CrossRef]

387. Gross, S.; Camozzo, D.; Di Noto, V.; Armelao, L.; Tondello, E. PMMA: A key macromolecular component for dielectric low-kappa hybrid inorganic-organic polymer films (Invited review). Eur. Polym. J. 2007, 43, 673-696. [CrossRef]

388. Sharma, R.C.; Chang, Y.A. The S-Zn (Sulfur-Zinc) System. Phase Diagr. Eval. Sect. II 1996, 17, $261-266$. [CrossRef]

389. Desgreniers, S.; Beaulieu, L.; Lepage, I. Pressure-induced structural changes in ZnS. Phys. Rev. B 2000, 61, 8726-8733. [CrossRef]

390. Gilbert, B.; Huang, F.; Zhang, H.; Waychunas, G.A.; Banfield, J.F. Nanoparticles: Strained and Stiff. Science 2004, 305, 651-654. [CrossRef] [PubMed]

391. Schrage, C.; Althues, H.; Klausch, A.; Adam, D.; Kaskel, S. ZnS:Cu Polymer Nanocomposites for Thin Film Electroluminescent Devices. J. Nanosci. Nanotechnol. 2010, 10, 4335-4340. [CrossRef] [PubMed] 
392. Guo, L.; Chen, S.; Chen, L. Controllable synthesis of ZnS/PMMA nanocomposite hybrids generated from functionalized ZnS quantum dots nanocrystals. Colloid Polym. Sci. 2007, 285, 1593-1600. [CrossRef]

393. Song, H.; Lee, S. Photoluminescent (CdSe) ZnS quantum dot-polymethylmethacrylate polymer composite thin films in the visible spectral range. Nanotechnology 2007, 18, 055402. [CrossRef]

394. Yuan, Y.; Krueger, M. Polymer-nanocrystal hybrid materials for light conversion applications. Polymers 2012, 4, 1-19. [CrossRef]

395. Anand, K.V.; Chinnu, M.K.; Kumar, R.M.; Mohan, R.; Jayavel, R. Thermal stability and optical properties of HMTA capped zinc sulfide nanoparticles. J. Alloy. Compd. 2010, 496, 665-668. [CrossRef]

396. Taherian, M.; Sabbagh Alvani, A.A.; Shokrgozar, M.A.; Salimi, R.; Moosakhani, S.; Sameie, H.; Tabatabaee, F. Surface-treated biocompatible ZnS quantum dots: Synthesis, photo-physical and microstructural properties. Electron. Mater. Lett. 2014, 10, 393-400. [CrossRef]

397. Yu, Z.; Ma, X.; Yu, B.; Pan, Y.; Liu, Z. Synthesis and characterization of ZnS:Mn/ZnS core/shell nanoparticles for tumor targeting and imaging in vivo. J. Biomater. Appl. 2013, 28, 232-240. [CrossRef] [PubMed]

398. Hermanson, G.T. Bioconjugate Techniques; Academic Press: New York, NY, USA, 2008.

399. Parfitt, G.D.; Patsis, A.V. Organic Coatings: Science and Technology; Marcel Dekker: New York, NY, USA, 1984.

400. Aswathy, J.; Jahnavi, S.; Krishna, R.; Manzoor, K.; Nair, S.; Menon, D. Targeted Labeling of Cancer Cells Using Biotin Tagged Avidin Functionalized Biocompatible Fluorescent Nanocrystals. J. Nanosci. Nanotechnol. 2011, 11, 7611-7620. [CrossRef] [PubMed]

401. Koneswaran, M.; Narayanaswamy, R. L-Cysteine-capped ZnS quantum dots based fluorescence sensor for $\mathrm{Cu}^{2+}$ ion. Sens. Actuators B Chem. 2009, 139, 104-109. [CrossRef]

402. Zhang, Y.; Peng, Q.; Wang, X.; Li, Y. Synthesis and Characterization of Monodisperse ZnS Nanospheres. Chem. Lett. 2004, 33, 1320-1321. [CrossRef]

403. Stöber, W.; Fink, A.; Bohn, E.J. Controlled growth of monodisperse silica spheres in the micron size range. J. Colloid Interface Sci. 1968, 26, 62-69. [CrossRef]

404. Li, Y.B.; Lu, W.; Huang, Q.A.; Huang, M.A.; Li, C.; Chen, W. Copper sulfide nanoparticles for photothermal ablation of tumor cells. Nanomedicine 2010, 5, 1161-1171. [CrossRef] [PubMed]

405. Kundu, J.; Pradhan, D. Controlled Synthesis and Catalytic Activity of Copper Sulfide Nanostructured Assemblies with Different Morphologies. ACS Appl. Mater. Interfaces 2014, 6, 1823-1834. [CrossRef] [PubMed]

406. Ohmasa, M.; Suzuki, M.; Takeuchi, Y. A refinement of the crystal structure of covellite, CuS. Miner. J. 1977, 8, 311-319. [CrossRef]

407. Thongtem, T.; Phuruangrat, A.; Thongtem, S. Synthesis and analysis of CuS with different morphologies using cyclic microwave irradiation. J. Mater. Sci. 2007, 42, 9316-9323. [CrossRef]

408. Chaki, S.H.; Tailor, J.P.; Deshpande, M.P. Synthesis and Characterizations of Undoped and Mn Doped CuS Nanoparticles. Adv. Sci. Lett. 2014, 20, 959-965. [CrossRef]

409. Biswas, S.; Hait, S.K.; Bhattacharya, S.C.; Moulik, S.P. Synthesis of Nanoparticles of CuI, $\mathrm{CuCrO}_{4}$, and CuS in Water/AOT/Cyclohexanone and Water/TX-100 + i-Propanol/Cyclohexanone Reverse Microemulsions. J. Dispers. Sci. Technol. 2005, 25, 801-816. [CrossRef]

410. Sugimoto, T.; Chen, S.; Muramatsu, A. Synthesis of uniform particles of CdS, ZnS, PbS and CuS from concentrated solutions of the metal chelates. Colloid Surf. A 1998, 135, 207-226. [CrossRef]

411. Raevskaya, A.E.; Stroyuk, A.L.; Kuchmii, S.Y.; Kryukov, A.I. Catalytic activity of CuS nanoparticles in hydrosulfide ions air oxidation. J. Mol. Catal. A Chem. 2004, 212, 259-265. [CrossRef]

412. Lin, L.; Li, X.; Yang, Y.; Jing, L.; Yue, X.; Chen, X.; Dai, Z. Chitosan Functionalized CuS Nanoparticles Boots Gene Transfection via Photothermal Effect. Curr. Drug. Deliv. 2016, 13, 1. [CrossRef]

413. Liu, R.F.; Jing, L.J.; Peng, D.; Li, Y.; Tian, J.; Dai, Z.F. Manganese (II) Chelate Functionalized Copper Sulfide Nanoparticles for Efficient Magnetic Resonance/Photoacoustic Dual-Modal Imaging Guided Photothermal Therapy. Theranostics 2015, 5, 1144-1153. [CrossRef] [PubMed]

414. Gong, Y.Y.; Liu, Y.Y.; Xiong, Z.; Kaback, D.; Zhao, D.Y. Immobilization of mercury in field soil and sediment using carboxymethyl cellulose stabilized iron sulfide nanoparticles. Nanotechnology 2012, 23, 294007. [CrossRef] [PubMed]

415. Van Koetsem, F.; Van Havere, L.; Du Laing, G. Impact of carboxymethyl cellulose coating on iron sulphide nanoparticles stability, transport, and mobilization potential of trace metals present in soils and sediment. J. Environ. Manag. 2016, 168, 210-218. [CrossRef] [PubMed] 
416. Xiong, Z.; He, F.; Zhao, D.Y.; Barnett, M.O. Immobilization of mercury in sediment using stabilized iron sulfide nanoparticles. Water Res. 2009, 43, 5171-5179. [CrossRef] [PubMed]

417. Dickinson, R.G.; Pauling, L. The crystal structure of molybdenite. J. Am. Chem. Soc. 1923, 45, $1466-1471$. [CrossRef]

418. Bakunin, V.N.; Suslov, A.Y.; Kuzmina, G.N.; Parenago, O.P. Synthesis and application of inorganic nanoparticles as lubricant components-A review. J. Nanoparticle Res. 2004, 6, 273-284. [CrossRef]

419. Kumar, N.; Seminario, J.M. Computational Chemistry Analysis of Hydrodesulfurization Reactions Catalyzed by Molybdenum Disulfide Nanoparticles. J. Phys. Chem. C 2015, 119, 29157-29170. [CrossRef]

420. Yan, Y.; Xia, B.Y.; Xu, Z.C.; Wang, X. Recent Development of Molybdenum Sulfides as Advanced Electrocatalysts for Hydrogen Evolution Reaction. ACS Catal. 2014, 4, 1693-1705. [CrossRef]

421. Sun, C.; Berg, J.C. Effect of moisture on the surface free energy and acid-base properties of mineral oxides. J. Chromatogr. A 2002, 969, 59-72. [CrossRef]

422. Ferretto, L.; Glisenti, A. Study of the surface acidity of an hematite powder. J. Mol. Catal. A Chem. 2002, 187, 119-128. [CrossRef]

423. Godocikova, E.; Balaz, P.; Bastl, Z.; Brabec, L. Spectroscopic study of the surface oxidation of mechanically activated sulphides. Appl. Surf. Sci. 2002, 200, 36-47. [CrossRef]

424. Mitchell, M.B. Fundamentals and Applications of Diffuse Reflectance Infrared Fourier Transform (DRIFT) Spectroscopy; American Chemical Society: Washington, DC, USA, 1993; Volume 236, pp. 351-375.

425. Noei, H.; Qiu, H.; Wang, Y.; Löffler, E.; Wöll, C.; Muhler, M. The identification of hydroxyl groups on ZnO nanoparticles by infrared spectroscopy. Phys. Chem. Chem. Phys. PCCP 2008, 10, 7092-7097. [CrossRef] [PubMed]

(C) 2017 by the authors. Licensee MDPI, Basel, Switzerland. This article is an open access article distributed under the terms and conditions of the Creative Commons Attribution (CC BY) license (http:/ / creativecommons.org/licenses/by/4.0/). 